\title{
Multihazard Risk Assessment for Planning with Climate in the Dosso Region, Niger
}

\author{
Maurizio Tiepolo $^{1, *(\mathbb{D})}$, Maurizio Bacci ${ }^{1,2}$ (D) and Sarah Braccio $^{1}$ \\ 1 Interuniversity Department of Regional and Urban Studies and Planning (DIST), Politecnico and University \\ of Turin, Viale G. Mattioli 39, 10125 Torino, Italy; maurizio.bacci@polito.it or m.bacci@ibimet.cnr.it (M.B.); \\ sarah.braccio@polito.it (S.B.) \\ 2 Ibimet CNR, Via G. Caproni 8, 50145 Florence, Italy \\ * Correspondence: maurizio.tiepolo@polito.it; Tel.: +39-011-090-7491
}

Received: 13 July 2018; Accepted: 6 August 2018; Published: 8 August 2018

\begin{abstract}
International aid for climate change adaptation in West Africa is increasing exponentially, but our understanding of hydroclimatic risks is not keeping pace with that increase. The aim of this article is to develop a multihazard risk assessment on a regional scale based on existing information that can be repeated over time and space and that will be useful during decision-making processes. This assessment was conducted in Dosso (Niger), the region most hit by flooding in the country, with the highest hydroclimatic risk in West Africa. The assessment characterizes the climate, identifies hazards, and analyzes multihazard risk over the 2011-2017 period for each of the region's 43 municipalities. Hazards and risk level are compared to the intervention areas and actions of 6 municipal development plans and 12 adaptation and resilience projects. Over the past seven years, heavy precipitation and dry spells in the Dosso region have been more frequent than during the previous 30-year period. As many as 606 settlements have been repeatedly hit and 15 municipalities are classified as being at elevated-to-severe multihazard risk. The geographical distribution of the adaptation and resilience projects does not reflect the risk level. A third of the local development plans examined propose actions that are inconsistent with the main hydroclimatic threats.
\end{abstract}

Keywords: risk analysis; drought; fluvial flood; pluvial flood; loss and damage; climate adaptation projects; local development plans; West Africa

\section{Introduction}

The Sendai Framework for disaster risk reduction [1] and the Sustainable Development Goals [2] recommend that more efforts should be made to carry out risk analysis with a holistic vision. This should orient a new generation of plans and projects towards communities that are most at risk, towards the main hydroclimatic threats, and should help monitoring, evaluation, communication [3], and awareness-raising activities [4]. In this article, with the term "risk", we mean "the combination of the probability of an event and its negative consequence" [5]. In the Global South, the multihazard approach is increasingly included in risk reduction plans [6] and in publications addressing risk on a local [7-13] and regional [14-18] scale. Nevertheless, the cases in which this approach has been used up to now reveal the difficulty of applying multihazard risk assessment methods and techniques that have been fine-tuned for countries boasting all the information and local expertise necessary [19-23] to areas that lack these characteristics. West Africa is a typical case. In this vast region, widespread warming, an increase in both the intensity and frequency of extreme heat waves, and heavy precipitation events [24-29] were combined with an increase in the number of hydroclimatic disasters [30] during the 1990-2010 period. The impact was catastrophic, considering the region's high reliance on rain-fed agriculture [31] and transhumant pastoralism. In the six years that followed, 
international aid earmarked $\$ 7.3$ billion for creating 715 climate change (CC) adaptation projects in West Africa's 17 countries [32]. These projects mainly operate on a local scale (districts and municipalities) and function alongside those that each individual country is already implementing with its own resources. Despite the fact that the terms "climate adaptation" and "resilience" constantly appear in these projects, the definition and location of actions cannot yet take advantage of either climate analysis, risk mapping [33], or disaster databases on a regional scale [34]. For example, subnational risk mapping lacks detail [35-38] and is mainly limited to floods. Multihazard risk is rarely taken into consideration. Risk is calculated using indicators that do not represent risk factors. The techniques involved are still too complex to be used at a local level or reproduced over time and space [39-53] (Table 1).

Table 1. Seventeen analyses on hydroclimatic risk in West Africa, 2005-2017 [39-53].

\begin{tabular}{|c|c|c|c|c|c|c|}
\hline Region & Country ISO & Area $\mathrm{Km}^{2}$ & Determinants of Risk * & Hazard & Technique & Reference \\
\hline Dassari ** & BEN & & $\mathrm{HV}$ & Flood/drought & Risk Index & [39] \\
\hline Dano ** & BFA & & $\mathrm{HV}$ & Flood/drought & Risk Index & [39] \\
\hline Vea ${ }^{* *}$ & GHA & & $\mathrm{HV}$ & Flood/drought & Risk Index & [39] \\
\hline Mono river basin & TOG & 406 & HEVA & Flood & Risk Index & [41] \\
\hline Mbo & NIG & 700 & $\mathrm{HV}$ & Flood/erosion & Spatial analysis & [42] \\
\hline Sinfra department & CDI & 1600 & $\mathrm{HV}$ & 2 Floods & Spatial analysis & [43] \\
\hline Ouémé basin & BEN & - & $\mathrm{H}$ & Flood & SPI & [46] \\
\hline Benin Niger basin & BEN & 9118 & $\mathrm{HEV}$ & Flood & Spatial analysis & [47] \\
\hline Man area & CDI & 12,100 & $\mathrm{HV}$ & Flood & Spatial analysis & [48] \\
\hline Sota basin & BEN & 13,410 & HV & Flood & Multicriteria & [49] \\
\hline Niger-Benoué basin & NIG & 13,702 & $\mathrm{E}$ & Flood & Spatial analysis & [50] \\
\hline
\end{tabular}

* V-Vulnerability; E-Exposure; HV-Hazard, Vulnerability; HEV-Hazard, Exposure, Vulnerability; HEVA-Hazard, Exposure, Vulnerability, Adaptation. ** The reference [39] identifies three study areas in three West African countries which have similar climates and are under varying forms of agricultural systems.

The goal of this article is to propose a multihazard risk assessment on a regional scale that will be useful during decision-making processes and that can be updated over time by personnel lacking advanced skills.

The achievement of this goal raises issues concerning (i) the characterization of hydroclimatic threats at regional level, (ii) the representation of the risk level according to administrative jurisdictions, (iii) the pertinence of risk reduction policies to climatic threats, and (iv) the setting up of the assessment in such a way that it can be repeated.

The assessment was carried out in the Dosso region $\left(31,000 \mathrm{~km}^{2}\right.$, with a population of 2 million) of Niger (Figure 1), the region most hit by flooding [53] in the West African country with the highest hydroclimatic risk [54].

The assessment considers pluvial flooding, fluvial flooding, and meteorological drought because other climatic hazards affecting Dosso (such as heat waves) are not systematically recorded at a municipal level. The three risks are then combined in a multihazard risk index (MHRI) with respect to the consistency of the period of time observed, the occurrence probability (1981-2017), the weight of risk determinants, the range of risk classes, the minimal unit of analysis (municipality), and the indicator measure (quantitative) [55].

The assessment is divided into four steps [56] (Figure 2).

The first step involves the context. Extreme rainfall events increased during the 1950-2014 period [57] in Niger. The aim is to ascertain the recent trend in hydroclimatic hazards regarding each individual municipality compared to the previous 30-year period. The information was provided by the Directorate National for Meteorology (with the French acronym DMN) from a rainfall estimate dataset taken from high-resolution satellites and from the River Niger Basin Authority (ABN). Next, the aim is to identify risk criteria (equation, probability of occurrence, level) and, as a result, the risk 
technique that should be used. The risk equation $(\mathrm{R})$ chosen combines hazard $(\mathrm{H})$, understood as the "potential occurrence of a natural physical event that may cause loss of life, injury[,] or damage to property" [58] and potential loss and damages (L\&D): $R=H^{*} L \& D$. The decision to use this equation instead of one that includes vulnerability and exposure $[59,60]$ was dictated by the impossibility of ascertaining accurately, for each municipality, the level of vulnerability and exposure. Digital elevation models (DEM) with an absolute accuracy (the difference between a point on the model and the same point on the ground) from 16-20 $\mathrm{m}$ (for SRTM and ASTER DEM) to $4 \mathrm{~m}$ (for 1:200,000 maps) and the spatial resolution of barely 250-1000 $\mathrm{m}$ of the satellite images (MODIS) commonly used in risk analysis in West Africa end up including settlements that are not prone to flooding. In view of these considerations, this risk assessment uses L\&D instead of vulnerability and exposure.

The second step involves risk identification. This step also identifies the L\&D datasets that should be used in the assessment, which settlements have been hit by different hydroclimatic events and how often over the past few years, the municipal development plans (MDPs), the adaptation and resilience projects that are being applied in the region that will help exemplify the use of the assessment, as well as the factors that turn floods and drought into disasters.

The third step involves the analysis of risk. This starts by understanding which risk, determinant, and indicator has a greater effect on the MHRI and then calculates the MHRI for each municipality in the region, representing it on a map.

The fourth step deals with the potential use of the assessment. This becomes clear when comparing the map of the MHRI with the intervention areas of the 12 projects for climate adaptation and resilience currently running in the region and with the adaptation actions envisaged by these projects and by six MDPs.

The most significant results of the assessment concern hazard characterization during the period examined, the level of single and multihazard risk, the municipalities that are neglected by $\mathrm{CC}$ adaptation and resilience projects, and the inconsistencies between categories of actions envisaged by MDPs and prevailing threats.

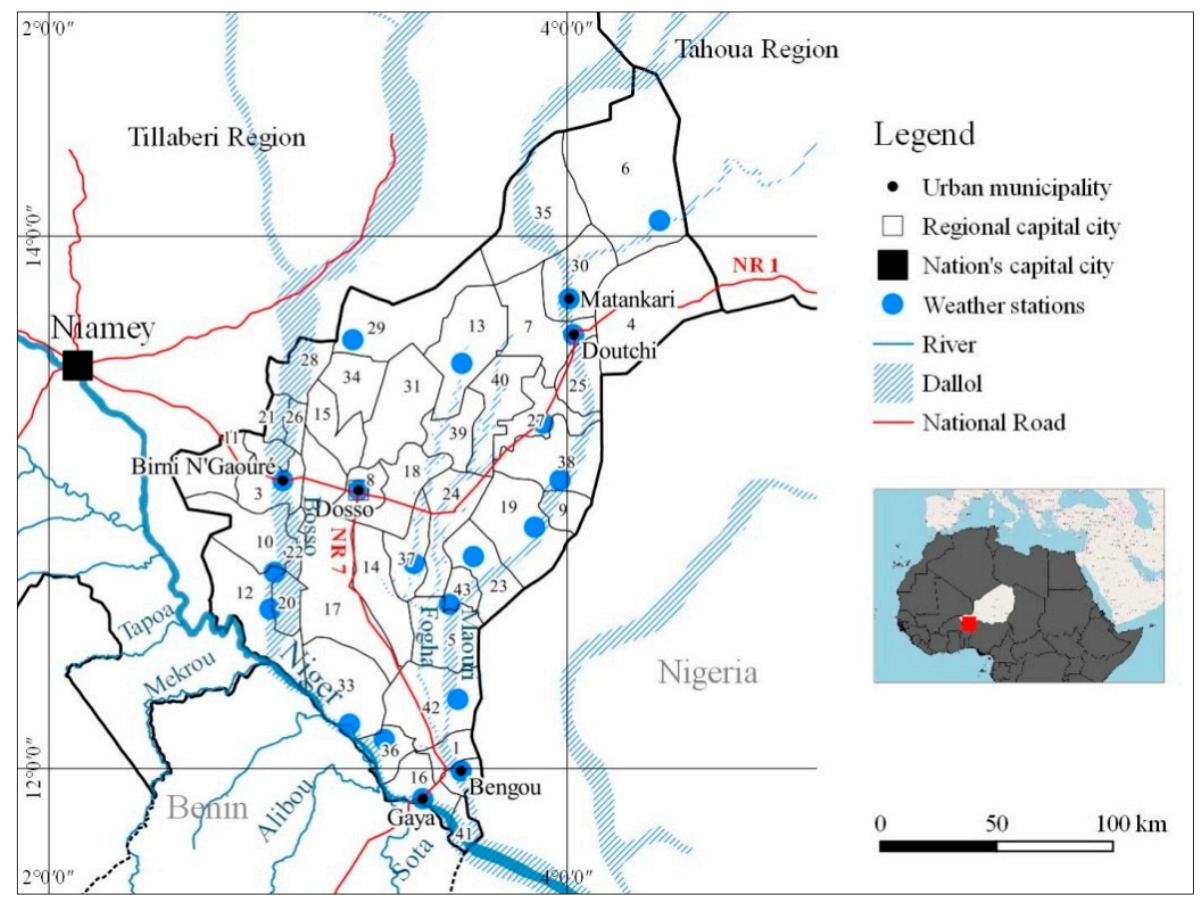

Figure 1. The 43 municipalities of the Dosso region, Niger. 


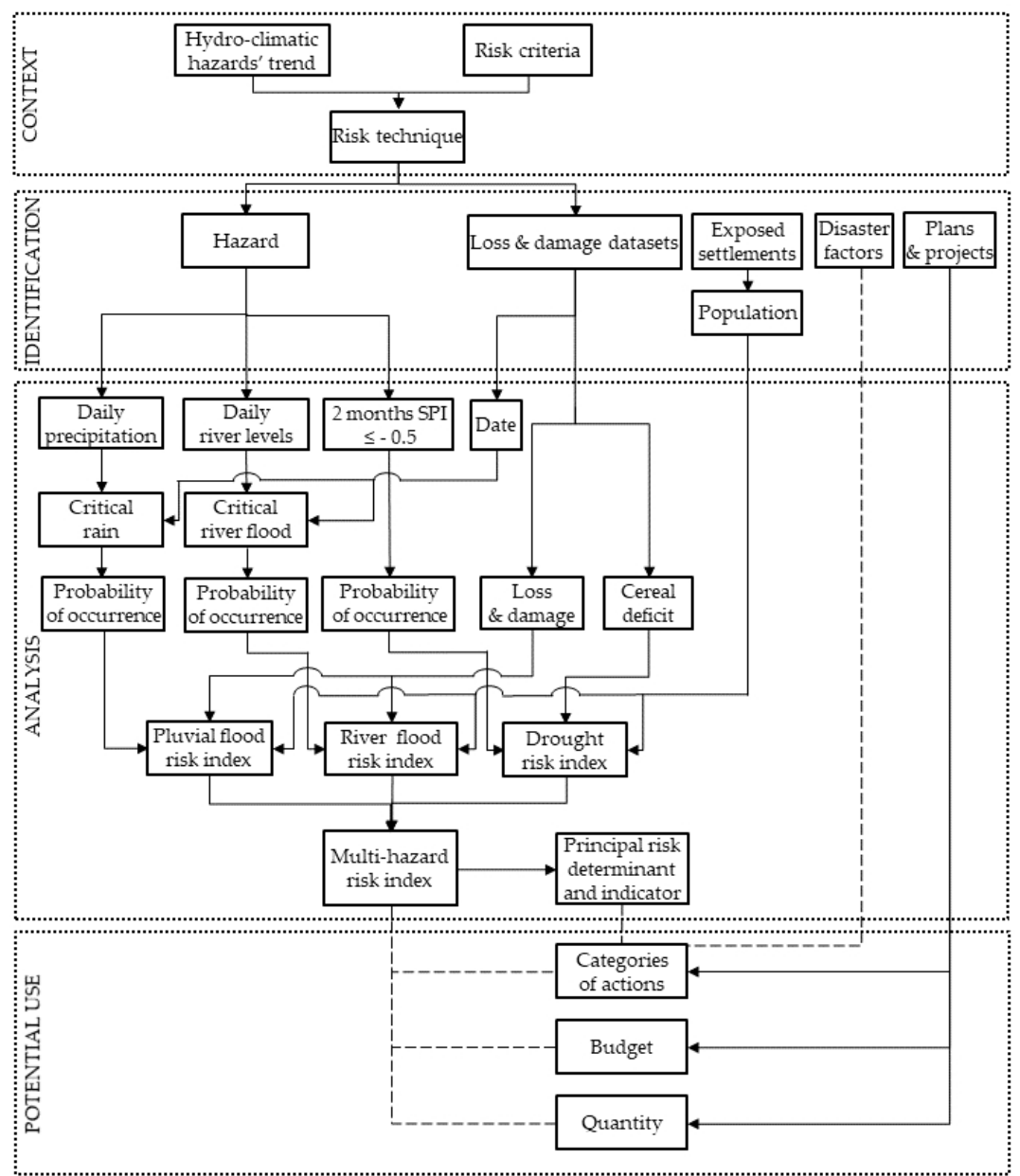

Figure 2. A schematic overview of the multihazard risk assessment [56].

\section{Materials and Methods}

\subsection{Context}

\subsubsection{Hazard Trends}

The context considered precipitation and river height over a period of 37 years (1981-2017). The Climate Hazards group InfraRed Precipitation with Stations (CHIRPS) dataset estimates daily rainfall on an almost global scale $\left(50^{\circ} \mathrm{S}-50^{\circ} \mathrm{N}, 180^{\circ} \mathrm{E}-180^{\circ} \mathrm{W}\right)$, with a resolution of $0.25^{\circ}$ [61]. This allowed us to understand the recent (2011-2017) spatial distribution of annual rainfall and heavy rains (over $20 \mathrm{~mm}$ ) compared to 1981-2010 climatology. Drought hazard is the probability of occurrence of at least two months during the farming season (June-September) of a Standardized Precipitation Index (SPI) that is equal to or less than -0.5 using the CHIRPS dataset for 2011-2017 with 1981-2010 as a reference period. The height of the River Niger was observed at the Malanville gauge (Benin), opposite the city of Gaya (Niger), using data from the ABN. These floods affect only five municipalities in the region and only the red ones are determined by local rainfalls conveyed into the river by the Bosso dallol and the right bank tributaries, such as the Sirba, the Mekrou, the Alibou, and the Sota.

\subsubsection{Risk Criteria}

Risk analysis was carried out using an historical approach [62] (what has happened over the past seven years) and the index technique. The MHRI was constructed using information regarding hazard $(\mathrm{H})$ and loss and damages $(\mathrm{L} \& \mathrm{D})$ : MHRI $=\mathrm{H}^{*} \mathrm{~L} \& \mathrm{D}$. This index is an alternative for all those cases 
in which the information available on vulnerability, exposure, and adaptive capacity is not precise or irregular, but instead, there is reliable and regularly collected information on loss and damage. It considers three risks to have a comparative view of the most frequent hydroclimatic threats in Niger and to identify, among them, the most relevant one.

The MHRI was divided up into five categories that are equally represented: severe (31.2-45.2), high (17.2-31.1), elevated (3.1-17.1), low (0.01-3), and negligible (0).

\subsection{Risk Identification}

\subsubsection{Dataset Identification}

The identification of L\&D was done by comparing three global open-access datasets (Desinventar, NatCatService, EM-DAT) and three national limited-access datasets (food security survey, flood L\&D, cereal deficit).

\subsubsection{Exposed Settlements}

Settlements exposed to pluvial and fluvial flooding and drought were identified using the names of the places listed in the two datasets chosen to appraise L\&D following disasters that took place during the 2011-2017 period. The names of the 1458 settlements extracted from the two datasets were linked to those in the National Repository of Human Settlements [63], which lists the geographic coordinates and the population of all Niger's populated places. Once this was done, it proved possible to produce exposure maps for each hazard. The municipal population was then used to compare the severity of L\&D with the demographic importance of the municipality within its region.

\subsubsection{Plans and Projects}

The MDPs were made available by Dosso's regional government. Each municipality has a plan. The plans developed after 2011 are second-generation versions in that they contain a snapshot analysis of the local climate and specific CC adaptation measures, as legally required by the Ministry of Spatial Planning and Community Development. The projects were identified by carrying out an Internet search using the keywords "risk reduction", "adaptation", "resilience", "project", and "program" in English and French, followed by the names of the 18 main multi-bilateral donors operating in Niger and checking the projects that emerged from this process against those known to Dosso's regional government.

\subsubsection{The Factors that Cause Disasters}

A focus group in the Falmey, Guéchémé, Kiéché, Tessa, and Tougouna municipalities, considered representative of the communities particularly hit by hydroclimatic disasters and at the same time of each agroecological zone of the region, was set up in 2018. This provides an understanding of the factors that turn hydroclimatic threats into disasters.

\subsection{Risk Analysis}

The risk analysis highlights, first and foremost, the principal risk, determinant, and indicator. It then goes on to calculate the MHRI as the sum of the pluvial flooding, fluvial flooding, and drought risk indices and represents this on a map.

The pluvial flood hazard used data from the DMN's network of weather stations in order to calculate more accurate rainfall figures. In this case, we identified the amount of daily precipitation that could lead to flooding (critical rainfall) for each disaster recorded in the Dosso region. We sought these figures in the days immediately preceding the disaster as recorded at the municipality's weather station or, in its absence, in that of adjacent municipalities located uphill from the municipality that reported damage. The inverse of return period was calculated using the methodology proposed by Gumbel [64] (Equations S1) considering the 1981-2017 period as a climatological reference. 
Drought hazard used the monthly SPI [65] for the months of the farming season in the region (June-September) using the CHIRPS dataset. The SPI index characterizes the deviation from normal rainfall; thus, the prolonged presence of negative figures identifies years when rain-fed crops could have problems. CHIRPS images provided figures for monthly SPI for each grid point in the region (Table S2). Each municipality could be associated with the grid point that fell within its bounds and therefore characterized hazard on a municipal scale.

River flood hazard was calculated from the height of the River Niger observed at the Malanville gauge (Benin) on the date of each disastrous flood and then assessed the inverse of return period within the 1981-2017 dataset of flood heights using the same procedure used for pluvial flooding.

Flood L\&D was measured using three indicators: the number of victims (L), the number of houses destroyed, and the surface area of flooded fields (D). The information was recorded by the Ministry of Humanitarian Action and Disaster Management (MAHGC) following 20 catastrophic floods that took place in the Dosso region from 2011 to 2017.

Drought L\&D was measured by a proxy indicator using the "cereal deficit" annually estimated by the Ministry of Agriculture and Livestock (MAE) for each settlement. For the purposes of this assessment, the deficit of each municipality was quantified as the average proportion of people who cannot be fed with locally produced cereals:

Drought L\&D year $\mathrm{x}=(\mathrm{P}$ cannot be fed with the local production of year $\mathrm{x} \times 100) / \mathrm{P}$ settlement year 2012

The total number of houses and the extent of fields in the Dosso region and its municipalities is not known. As a result, the L\&D for each municipality was linked to its population, and the resulting figure was linked to the comparison between regional L\&D and the region's population:

Rmunicipality $\mathrm{x}=$ Hmunicipality $\mathrm{x} \times($ L\&Dmunicipality $\mathrm{x} /$ Pmunicipality $\mathrm{x}) /($ L\&Dregion/Pregion $)$

where:

$\mathrm{H}=$ probability of occurrence of a rainy day having caused L\&D during the 2011-2017 period;

$\mathrm{L} \& \mathrm{D}=$ loss and damages during the 2011-2017 period;

$\mathrm{P}=$ population according to the 2012 national census [63].

In other words, L\&D is compared to the demographic weight of each municipality in the region. The MHRI is obtained by summing up the individual risks calculated for each of the 43 municipalities of the Dosso region (Figure 3).

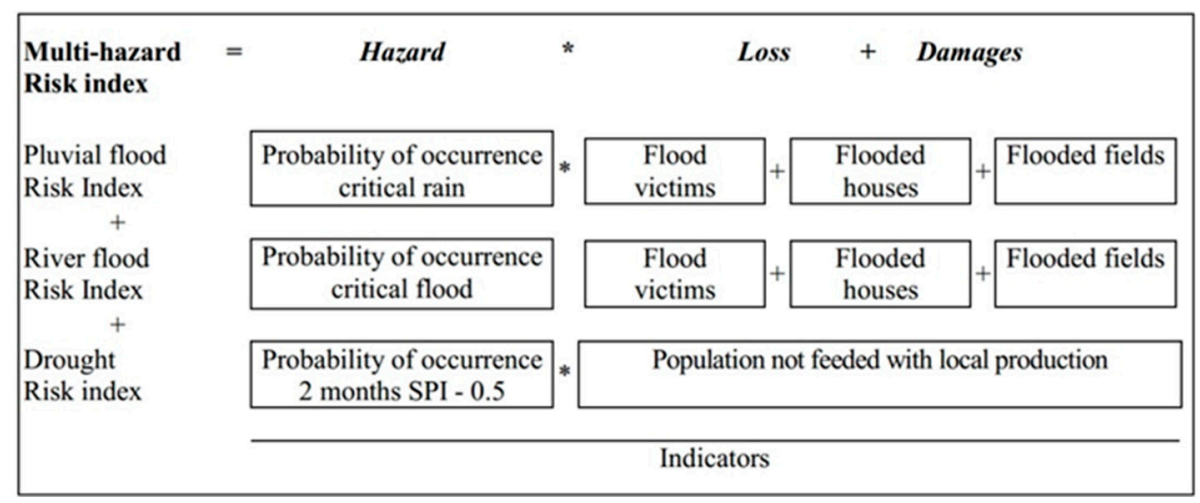

Figure 3. Risk determinants and indicators.

\subsection{The Potential Use of the Risk Index and Maps}

The potential applications of the multihazard risk assessment became clear when comparing the principal risk, determinant, and indicator with the categories of actions, the budget, and the number 
of plans [66-71] and projects [72-83] that are underway in the region. Information regarding actions was sourced from the intermediate and final evaluation reports of individual projects. The actions were grouped according to the categories defined by Biagini et al. [84] to make the analysis of consistency easier.

\subsection{Uncertainties}

The greatest uncertainties concerned basic information (the geographical density of weather stations, the location and population of settlements that were hit by flooding and drought, and the level of cereal deficit). Municipalities lacking a weather station with a dataset of at least 30 years were attributed the rainfall measurement of the weather station closest to them and located uphill. The settlements with an unspecified level of deficit were given the average deficit level of the municipality to which they belong. The method remains valid despite such guesswork. For the purposes of this assessment, it was enough to consider that the level of risk for the municipalities lacking information might be underestimated or overestimated.

\section{Results}

\subsection{Context}

\section{Hazard Trends}

During the 2011-2017 period, there was a reduction in rainfall of $20-40 \mathrm{~mm}$ /year throughout the region compared to the 1981-2010 period (Figure 4). Nevertheless, in the municipalities of BirniN'Gaoure, Dan Kassari, Dogon Kirya, Loga, Matankari, N'Gonga, and Soucoucoutane $(3,4,6$, $29,30,32$, and 35 at Figure 5), despite the reduction in annual accumulated rainfall, the number of extremely heavy precipitation days $(>20 \mathrm{~mm})$ increased.

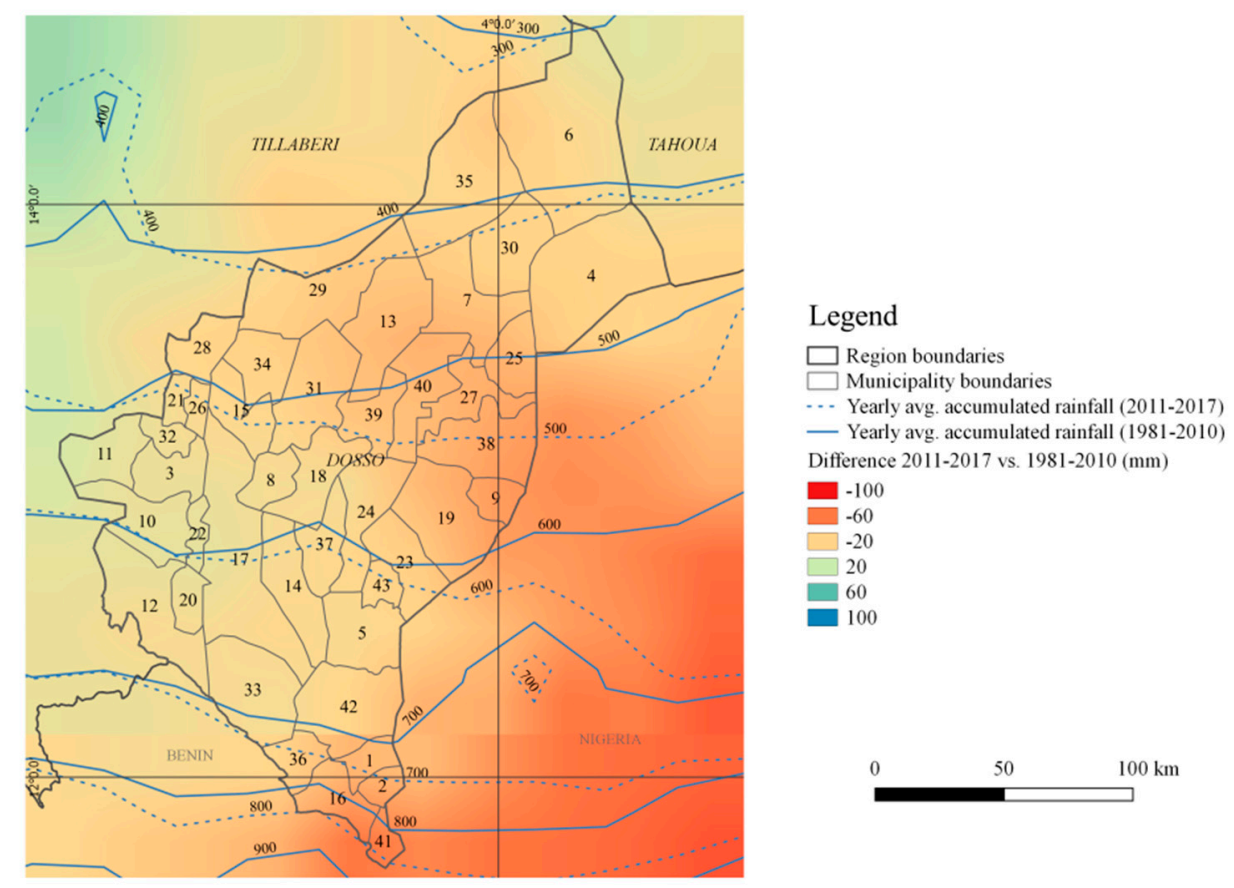

Figure 4. The difference in average accumulated rainfall during 2011-2017 and 1981-2010 (rainfall data from the Climate Hazards group InfraRed Precipitation with Stations (CHIRPS) dataset). 


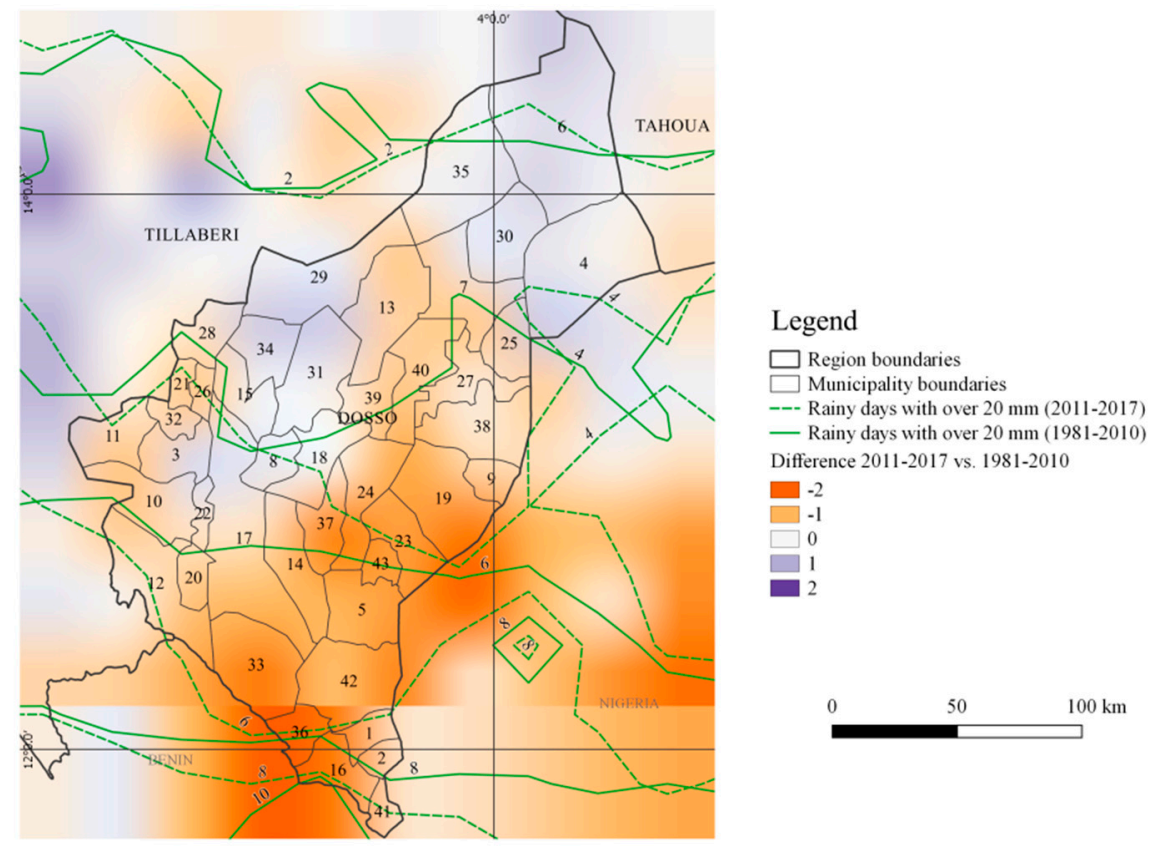

Figure 5. The difference in the average number of rainy days with over $20 \mathrm{~mm}$ in the 2011-2017 and 1981-2010 periods (rainfall data from CHIRPS).

The increase in the frequency of extremely heavy precipitation days increases the probability of creating conditions that can lead to pluvial flooding.

The distribution of the number of dry days and the number of spells with at least five dry days during the growing season differs from one part of the region to another, with figures that rise as high as +2 days in the longest stretch of drought and +1 dry spell of at least five days during the growing season (Figure 6).

The northern and western parts of the region particularly suffer from more extreme conditions of drought. Over the past seven years, the municipalities of Birni N'Gaoure (3 at Figure 6), Dosso (8), Fakara (11), Falmey (12), Garankedey (15), Golle (17), Gorou Bakassam (18), Harikanassou (21), Kiota (26), Koygolo (28), Ngonga (32), Sokorbe (34), Soucoucoutane (35), and Tessa (37) have recorded many prolonged droughts. The municipalities of Dogon Kiria, Falwel, Kore Mairoua, Loga, Matankari, Mokko, Sakadamna, and Tombokoarey I only recorded a larger number of dry spells of at least 5 days during the growing season. This unequal distribution of rainfall increases the risk that the harvest of rain-fed crops will be lost.

The River Niger's annual cycle features two floods. One flood takes place during the wet season, fed by local precipitation and known as a "red flood" due to the color of the sediment carried by the water. The other flood takes place during the dry season and is called a "Guinean flood" because it is caused by precipitation in the part of Guinea that this great river crosses. Red floods are usually slightly higher than Guinean floods. Over the past six years, red floods have considerably exceeded Guinean floods and have reached particularly high levels compared to the previous 31 years (Figure 7). 


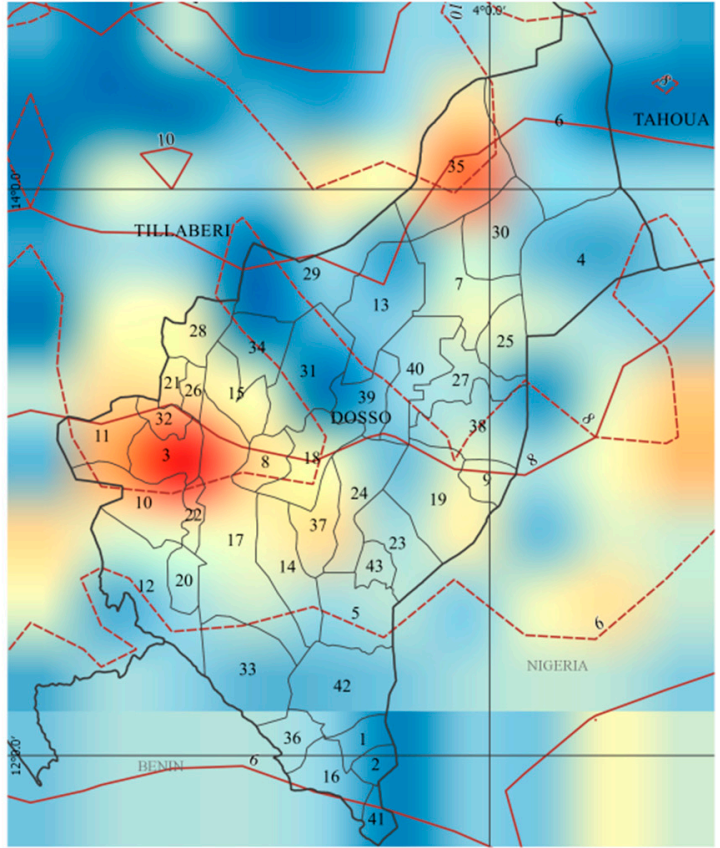

(a)

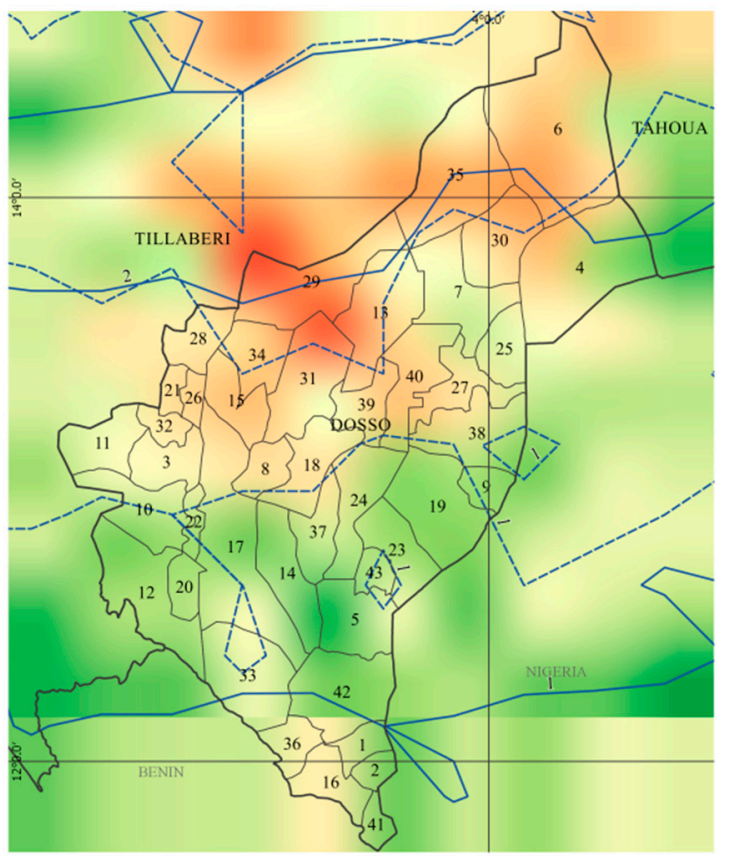

(b)

\section{Legend}

$\square$ Region boundaries

$\square$ Municipality boundaries

--- Max. num. of consecutive dry days (2011-2017)

- Max. num. of consecutive dry days (1981-2010)

Difference 2011-2017 vs. 1981-2010

$\square-2$

$\square-1$

1

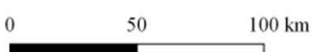

$100 \mathrm{~km}$

\section{Legend}

$\square$ Region boundaries

$\square$ Municipality boundaries

--- Num. dry spells of at least five days (2011-2017)

- Num. dry spells of at least five days (1981-2010)

Difference 2011-2017 vs. 1981-2010

$-1$

$\square-0$

0
$\square$

1

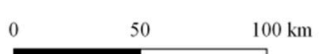

Figure 6. The difference in the maximum number of consecutive dry days between 2011-2017 and 1981-2010 (a); the difference in the number of spells of at least five dry days between 2011-2017 and 1981-2010 (b) (rainfall data from CHIRPS). 


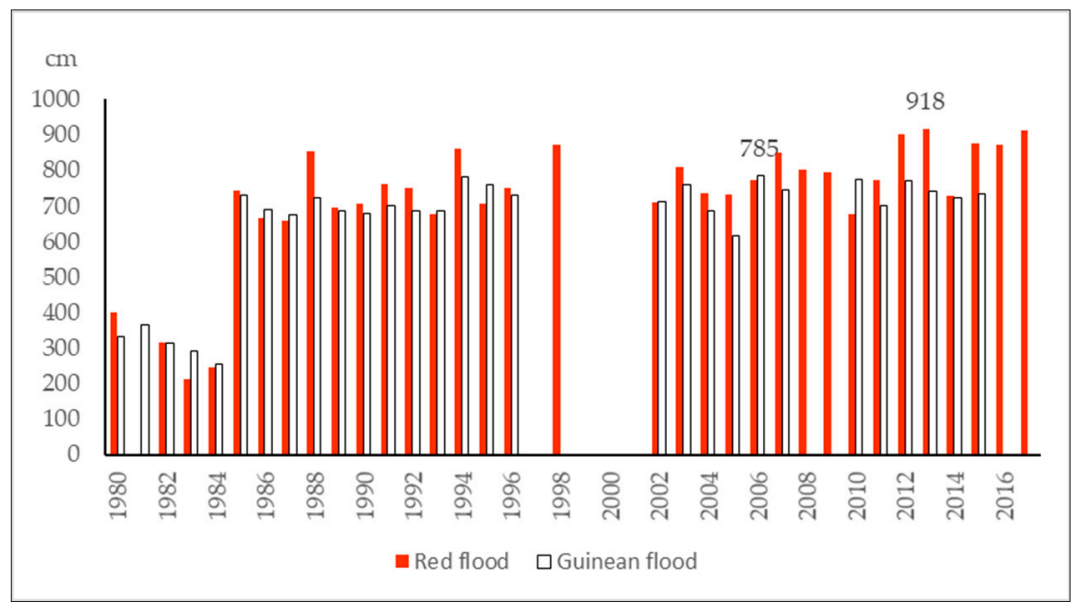

Figure 7. Peaks of the River Niger at Malanville (Benin) during local (red) and Guinean (white) floods, 1980-2017.

\subsection{Risk Identification}

\subsubsection{Dataset Identification}

As far as risk identification is concerned, six datasets on L\&D were compared. Desinventar, a product of the project sponsored by UNISDR [85], is an open-access worldwide database on disasters. In the Dosso region, Desinventar covers the 1988-2013 period and, therefore, only part of the period considered here (2011-2017), during which eight floods and one drought were recorded. EM-DAT [30], produced by Louvain Catholic University, recorded 12 events on a national scale during the 2011-2017 period. NatCatService [86], produced by Munich RE, recorded five hydroclimatic events in Niger from 2011 to 2017. The Joint Survey on Vulnerability to Food Insecurity [87], compiled by the Coordination Unit of the Early Warning System (CC/SAP) on a national scale, contains information on the victims and causes of flooding. In the Dosso region, the survey is conducted through interviews with households. It does not produce electronic data on a municipal scale and does not cover the region's seven urban areas. The Flood dataset $[88,89]$ was compiled from 1998 to 2011 by the CC/SAP on a national scale in conjunction with the National Device for the Prevention and Management of Food Crises, which operates on the ground with the Community Early Warning System and Emergency Response (SCAP-RU) and the Observatories for Vulnerability Monitoring (OSV). From 2012 to 2015, this task was handed over to the Humanitarian Coordination Unit and subsequently to the MAHGC. The dataset records flooded settlements, their geographic coordinates, the date flooding took place (20 events from 2011 to 2017), the duration of the event, and the loss (victims) and damage (houses, fields, livestock, infrastructure). The List of Deficit Settlements is drafted every year by the MAE [90] and estimates crop yields in sample villages chosen at random. Deficit is worked out by comparing estimated production with the requirement of local inhabitants using a standard per capita consumption figure of $231 \mathrm{~kg}$ of cereal per year. The list states the level of deficit caused by drought (a late start and an early end to the growing season, dry spells) per settlement. From 2011 to 2017, drought took place every year. For assessment purposes, we chose MAHGC and MAE datasets due to their greater detail, more up-to-date information, and the fact that they are updated on an annual basis.

\subsubsection{Exposed Settlements}

Pluvial flooding hits $6 \%$ of the region's settlements (24 settlements are repeatedly flooded) and $17 \%$ of the population. By population, here, we mean the entire population of the affected settlements, not the population actually damaged. This is because, especially in the smaller settlements, it is the 
entire population that is involved in mutual aid after the disaster and suffers from the inconvenience caused by the temporary interruption of infrastructure operation. Almost all of these settlements are located in the dallols (old river beds with a shallow water table) that are prone to runoff when extreme rains occur. When the River Niger bursts its banks, it affects $1 \%$ of the region's settlements (36 settlements, of which 15 are repeatedly flooded) and 2\% of the region's population (Figure 8).

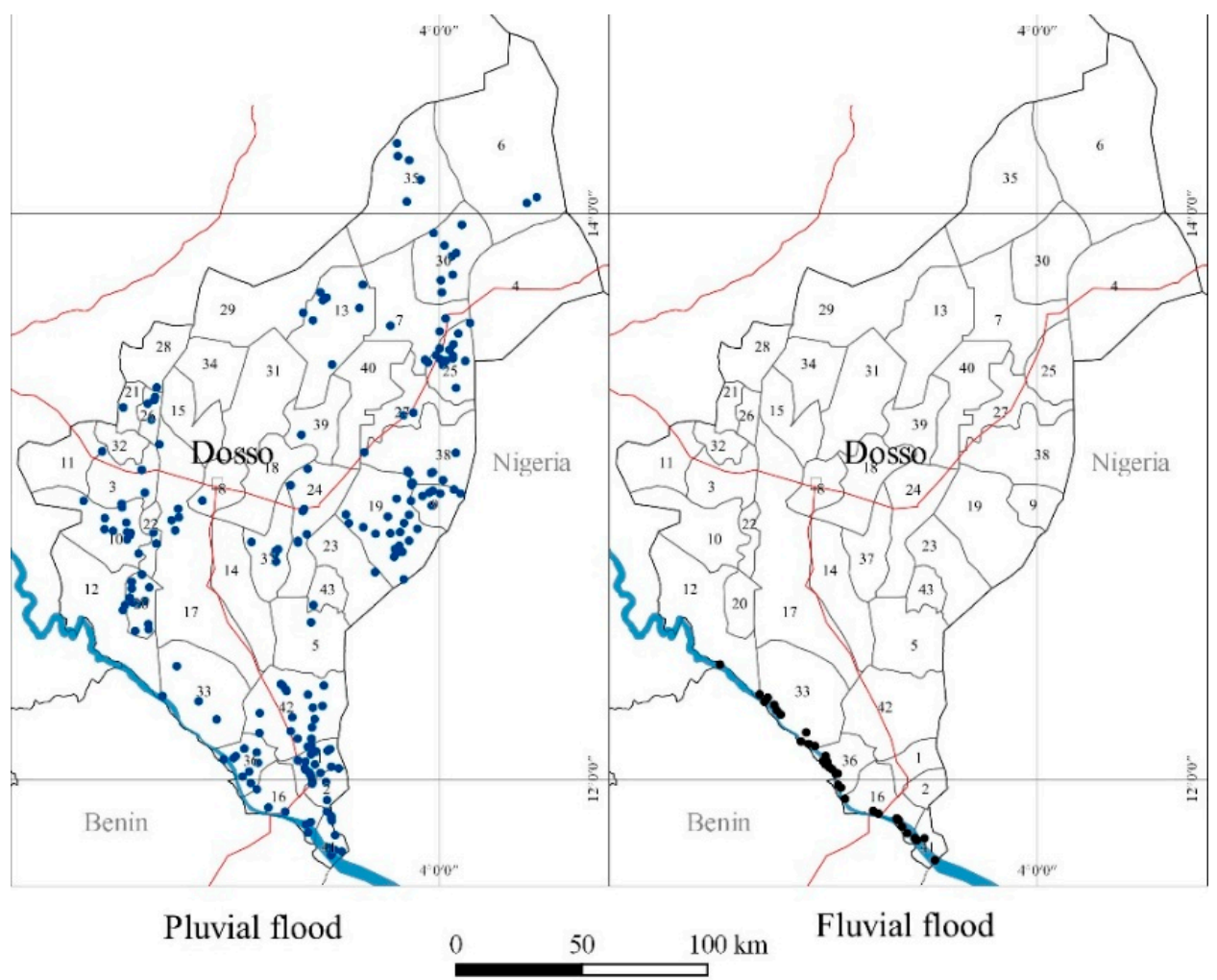

Figure 8. Settlements of the Dosso region affected more than one year (dots) by pluvial flooding (left) and fluvial flooding (right) from 2011 to 2017.

Drought affects $24 \%$ of settlements and $48 \%$ of the population (548 settlements are hit twice or more, particularly in the central part of the region) (Figure 9).

It is more common for the same settlements to be repeatedly affected by drought $(48 \%$ of settlements) and fluvial flooding (42\% of settlements) as opposed to pluvial flooding (only $8 \%$ ). Two percent of settlements are hit by drought and pluvial floods in 31 municipalities, particularly the Guéchémé, Bana, and Fabidji municipalities (19, 1, and 10 at Figure 8, Table 2 and Table S3). Thirty-eight settlements are hit by pluvial floods and drought in the same year. All urban settlements are affected. Twenty-nine percent of settlements located in a buffer zone of $500 \mathrm{~m}$ from the banks of the River Niger and $20 \%$ of those found in the dallols have been flooded over the past seven years. 


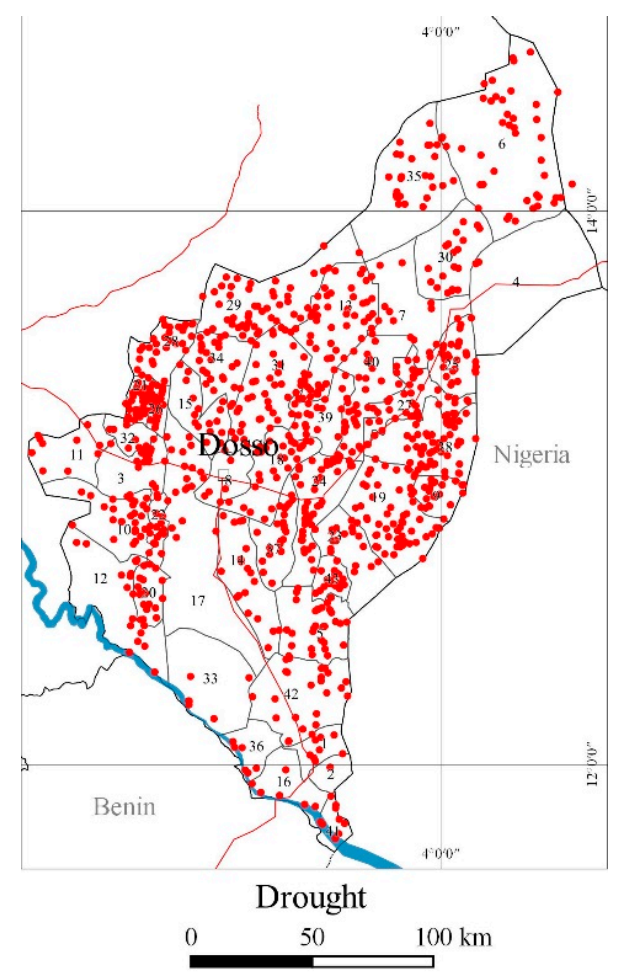

Figure 9. Settlements of the Dosso region affected more than one year (dots) by drought from 2011 to 2017.

Table 2. Human settlements in the Dosso region flooded and affected by agricultural drought from 2011 to 2017.

\begin{tabular}{ccccc}
\hline Settlements & Pluvial Flood & Fluvial Flood & Drought & Multihazard \\
\hline $\begin{array}{c}\text { Number } \\
\text { of regional }\end{array}$ & 277 & 36 & 1135 & 121 \\
$\begin{array}{c}\text { settlements } \\
\text { Population number }\end{array}$ & 645,859 & 1 & 24 & 2 \\
$\begin{array}{c}\% \text { of regional } \\
\text { population }\end{array}$ & 17 & 32,167 & 987,842 & 235,826 \\
\hline
\end{tabular}

\subsubsection{Plans and Projects}

Six MDPs, representing municipalities at severe, high, and elevated risk, and the 12 adaptation and resilience projects currently underway or recently completed in the region of Dosso by the state and international aid organizations were identified. The categories of actions, their budgets, and the municipalities benefiting from these projects were compared to the risk, the determinant, and the key indicator as well as to the MHRI in order to demonstrate the potential use of the risk assessment.

\subsubsection{Factors that Contribute to Causing Disasters}

Thanks to focus groups organized in five settlements selected to represent each agroecological zone of the region, the factors that turn flooding and drought into a disaster were ascertained (Table 3).

In the case of pluvial flooding, a critical factor is the absence of protection for receptors, while in the case of fluvial flooding, it is the absence of an early warning system. In the case of drought, critical factors include the lack of a rain gauge, which would allow farmers to choose to sow rain-fed crops when enough rain has fallen, the use of drought-resistant cultivars that ripen before the rainy season comes to an early end, and insufficient soil and water conservation that help in managing soil moisture. 
Table 3. Factors contributing to disastrous floods and drought as ascertained in Falmey, Guéchemé, Kiéché, Tessa, and Tounouga municipalities in July 2018.

\begin{tabular}{lll}
\hline \multicolumn{1}{c}{ Hazard } & \multicolumn{1}{c}{ Impact } & \multicolumn{1}{c}{ Disaster Factors } \\
\hline Pluvial flood & Houses collapse & $\begin{array}{l}\text { Lack of elevated threshold at house } \\
\text { entrance }\end{array}$ \\
\hline & & Lack of corrugated iron roof \\
\hline & Reduced access to water & Lack of plaster \\
\hline Fluvial flood & Environmental pollution & Unraised basement of wells and fountains \\
\hline Fluvial and pluvial flood & Loss of livestock, agricultural tools & Lack of early warning \\
\hline \multirow{2}{*}{ Drought } & Houses collapse & Lack of unraised basement \\
\hline & Crop loss & $\begin{array}{l}\text { Lack of rain gauge } \\
\text { Lack of drought-resistant cultivars } \\
\text { Lack of water and soil conservation }\end{array}$ \\
\hline
\end{tabular}

\subsection{Risk Analysis}

The Principal Risk, Determinant, and Indicator

One of the first aspects that should be taken into account when analyzing multihazard risk is which risk, determinant (H or L\&D), and, of the latter, which indicator (victims, houses, fields, crop failure) counts more when determining the MHRI. This analysis allows us to verify whether the actions developed by plans and projects address the risk, determinant, and key indicator.

The risk of pluvial flooding influences the MHRI the most (Figure 10a). The recurrence period of pluvial flooding varies from 0.08 to 1 . The maximum figure indicates a disastrous event that could reoccur on an annual basis, as in Dosso, Falmey, and Gourou Bankassam. In 10 municipalities, there were no critical events in the period from 1981 to 2017. The recurrence period of fluvial flooding varies from 0.3 to 0.6 (Tounouga), while meteorological drought varies from 0.5 (8 municipalities) to 0.83 (14 municipalities). L\&D due to pluvial flooding is higher in the municipalities of Bengou, Bana, and Tounouga, while L\&D due to fluvial flooding is higher in Tanda, Tounouga, and Gaya, and vulnerability to drought is higher in Doumega and Bana. The level of risk is determined by L\&D and hardly ever by its hazard (Figure 10b).

The decisive indicator is flooded fields, which in the case of fluvial flooding are particularly widespread (Figure 10).

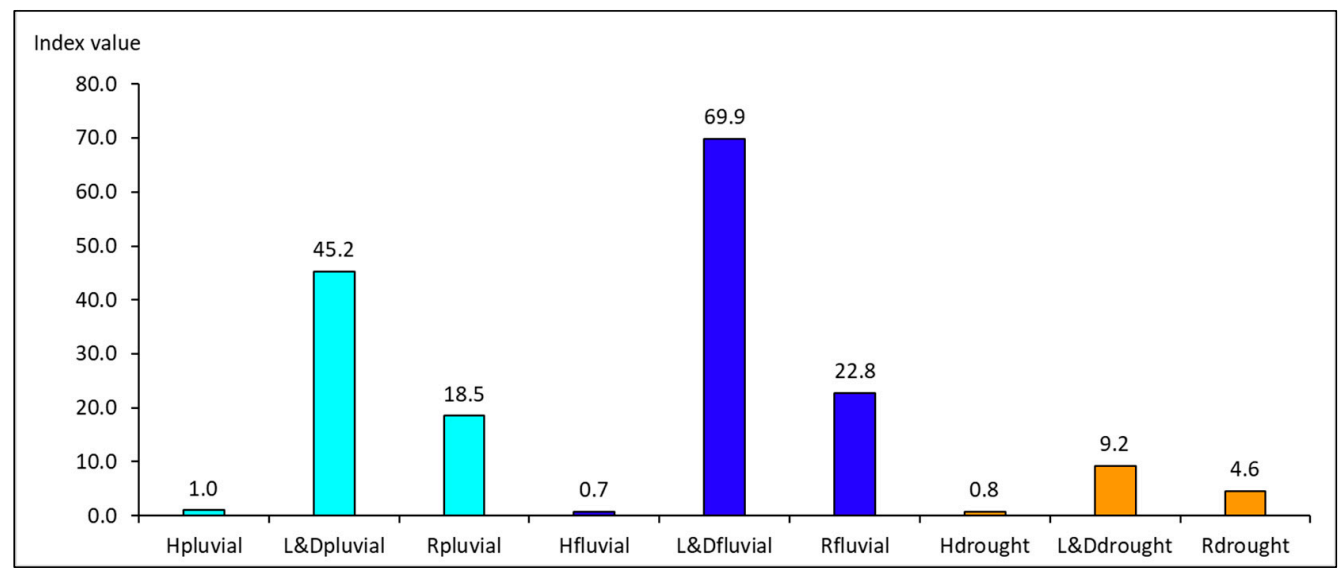

(a)

Figure 10. Cont. 


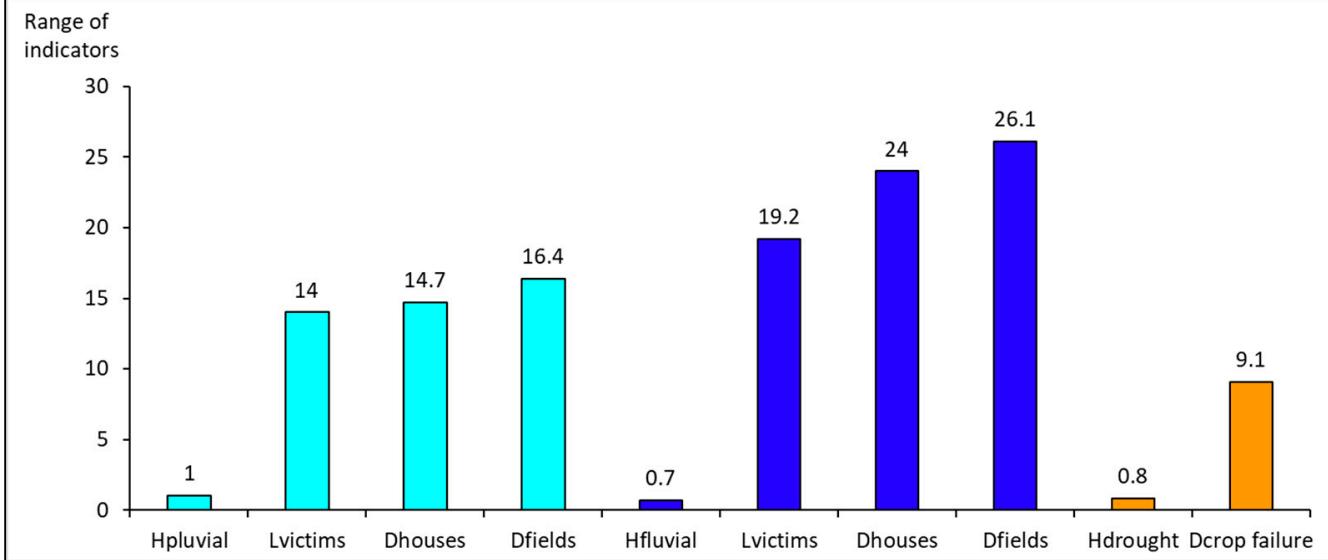

(b)

Figure 10. The importance of the single components of risk in the Dosso region according to threat, 2011-2017 (a) and the range of indicators of pluvial flooding, fluvial flooding, and drought risk (b) using data from Table 4.

Table 4. Multihazard risk level at the municipal scale in the Dosso region, 2011-2017 (H-Hazard, D-Loss \& Damage, R-Risk).

\begin{tabular}{|c|c|c|c|c|c|c|c|c|c|c|}
\hline \multirow{2}{*}{ Municipality } & \multicolumn{3}{|c|}{ Pluvialflood } & \multicolumn{3}{|c|}{ Fluvialflood } & \multicolumn{3}{|c|}{ Drought } & \multirow{2}{*}{$\begin{array}{c}\text { Multihazard } \\
\text { R }\end{array}$} \\
\hline & $\mathbf{H}$ & D & $\mathbf{R}$ & $\mathbf{H}$ & D & $\mathbf{R}$ & $\mathbf{H}$ & $\mathrm{D}$ & $\mathbf{R}$ & \\
\hline 1 Bana & 0.1 & 22.8 & 0.91 & & & & 0.8 & 2.4 & 2.0 & 2.9 \\
\hline 2 Bengou & 1 & 45.2 & 45.17 & & & & 0.8 & 0 & 0 & 45.2 \\
\hline 3 Birni N'Gaoure & 1 & 1.4 & 1.41 & & & & 0.8 & 0.4 & 0.3 & 1.7 \\
\hline 4 Dan Kassari & 1 & 0.6 & 0.64 & & & & 0.8 & 1.1 & 0.9 & 1.6 \\
\hline 5 Dioudiou & 1 & 1.0 & 0.97 & & & & 0.5 & 0.2 & 0.1 & 1.1 \\
\hline 6 Dogon Kiria & 0.99 & 0 & 0.03 & & & & 0.7 & 0.8 & 0.5 & 0.6 \\
\hline 7 Dogondoutchi & 1 & 3.4 & 3.37 & & & & 0.5 & 0.7 & 0.4 & 3.8 \\
\hline 8 Dosso & 1 & 0 & 0 & & & & 0.7 & 0.2 & 0.1 & 0.1 \\
\hline 9 Doumega & 1 & 4.1 & 4.05 & & & & 0.5 & 9.2 & 4.6 & 8.6 \\
\hline 10 Fabidji & 0.1 & 4.8 & 0.48 & & & & 0.7 & 1.9 & 1.3 & 1.7 \\
\hline 11 Fakara & 0.02 & 0 & 0 & & & & 0.8 & 1.7 & 1.4 & 1.4 \\
\hline 12 Falmey & 1 & 2.1 & 2.14 & 0.3 & 2.7 & 0.9 & 0.8 & 0.3 & 0.2 & 3.3 \\
\hline 13 Falwel & 1 & 0.8 & 0.78 & & & & 0.7 & 1.6 & 1.0 & 1.8 \\
\hline 14 Farrey & 1 & 0 & 0 & & & & 0.7 & 0.5 & 0.3 & 0.3 \\
\hline 15 Garankedey & 0.93 & 1.1 & 1.04 & & & & 0.7 & 1.7 & 1.1 & 2.2 \\
\hline 16 Gaya & 1 & 3.0 & 3.03 & 0.3 & 18.4 & 6.1 & 0.8 & 0.1 & 0.1 & 9.2 \\
\hline 17 Golle & 1 & 0.1 & 0.14 & & & & 0.7 & 0.4 & 0.2 & 0.4 \\
\hline 18 GoroubanKassam & 1 & 0 & 0 & & & & 0.7 & 0.9 & 0.6 & 0.6 \\
\hline 19 Guéchémé & 1 & 5.1 & 5.07 & & & & 0.5 & 1.3 & 0.6 & 5.7 \\
\hline 20 Guilladjé & 1 & 9.0 & 8.98 & & & & 0.7 & 0.4 & 0.3 & 9.3 \\
\hline 21 Harikanassou & 1 & 0 & 0.02 & & & & 0.8 & 1.9 & 1.5 & 1.6 \\
\hline 22 Kankandi & 0.33 & 1.2 & 0.41 & & & & 0.0 & 0.3 & 0 & 0.4 \\
\hline 23 KaraKara & 1 & 0.8 & 0.83 & & & & 0.7 & 1.7 & 1.2 & 2.0 \\
\hline 24 KarguiBangou & 1 & 6.8 & 6.84 & & & & 0.7 & 0.9 & 0.6 & 7.5 \\
\hline 25 Kieché & 1 & 2.8 & 2.8 & & & & 0.8 & 0.7 & 0.5 & 3.4 \\
\hline 26 Kiota & 1 & 1.6 & 1,59 & & & & 0.8 & 1.7 & 1.4 & 3.0 \\
\hline 27 Kore Mairoua & 1 & 1.4 & 1.43 & & & & 0.7 & 1.6 & 1.0 & 2.2 \\
\hline 28 Koygolo & 1 & 0.5 & 0.48 & & & & 0.5 & 1.0 & 0.5 & 2.5 \\
\hline
\end{tabular}


Table 4. Cont.

\begin{tabular}{lcccccccccc}
\hline \multirow{2}{*}{ Municipality } & \multicolumn{3}{c}{ Pluvialflood } & \multicolumn{3}{c}{ Fluvialflood } & \multicolumn{3}{c}{ Drought } & \multicolumn{3}{c}{ Multihazard } \\
\cline { 2 - 11 } & H & D & R & H & D & R & H & D & R & R \\
\hline 29 Loga & 1 & 0 & 0 & & & & 0.5 & 1.0 & 0.5 & 0.5 \\
30 Matankari & 1 & 3.0 & 2.98 & & & & 0.5 & 0.8 & 0.4 & 3.4 \\
31 Mokko & 1 & 0 & 0 & & & & 0.8 & 1.4 & 1.2 & 1.2 \\
32 N'Gonga & 0.9 & 1.0 & 0.92 & & & & 0.8 & 0.4 & 0.3 & 1.2 \\
33 Sambera & 1 & 1.6 & 1.55 & 0.5 & 7.8 & 3.8 & 0.5 & 0.10 & 0.1 & 5.4 \\
34 Sokorbé & 1 & 0 & 0 & & & & 0.7 & 0 & 0 & 0 \\
35 Soucoucoutane & 1 & 1.3 & 1.33 & & & & 0.7 & 0.9 & 0.6 & 2.0 \\
36 Tanda & 1 & 5.0 & 4.97 & 0.3 & 69.3 & 22.9 & 0.7 & 0.2 & 0.1 & 28.0 \\
37 Tessa & 1 & 2.0 & 1.96 & & & & 0.7 & 1.1 & 0.8 & 2.7 \\
38 Tibiri & 1 & 1.0 & 1.01 & & & & 0.7 & 0.7 & 0.5 & 1.5 \\
39 TomboKoarey I & 1 & 1.0 & 1.03 & & & & 0.7 & 1.5 & 1.0 & 2.1 \\
40 TK II-Sakadamna & 0.1 & 0 & 0 & & & & 0.7 & 0.7 & 0.5 & 0.5 \\
41 Tounouga & 1 & 21.5 & 21.51 & 0.7 & 20.4 & 13.7 & 0.8 & 0.5 & 0.5 & 35.6 \\
42 Yelou & 1 & 4.4 & 4.36 & & & & 0.8 & 0.5 & 0.5 & 4.8 \\
43 Zabori & 1 & 0 & 0 & & & & 0.7 & 1.3 & 0.9 & 0.9 \\
\hline
\end{tabular}

\subsection{From Single to Multihazard Risk Levels}

Risk (R) is worked out by summing the probability of occurrence of a hydroclimatic event $(\mathrm{H})$ and the L\&D caused from 2011 to 2017: $R=H^{*}$ L\&D.

When it comes to individual hazards (pluvial flooding, fluvial flooding, drought), the municipalities with a risk level higher than 1 demonstrate a risk that is higher than their demographic weight in the region. Pluvial risk affects 37 municipalities: severe in Bengou ( 2 at Figure 10), high in Tounouga (41 at Figure 10), and elevated in municipalities crossed by the dallols, particularly in Guilladje (20), KarguiBangou (29), and Guechémé (19). Fluvial flood risk affects five municipalities and is severe in Tanda (36) and high in Tounouga (41). Drought risk is present in 41 municipalities but with a low level and reaches a peak in Doumega (9 at Figure 11).

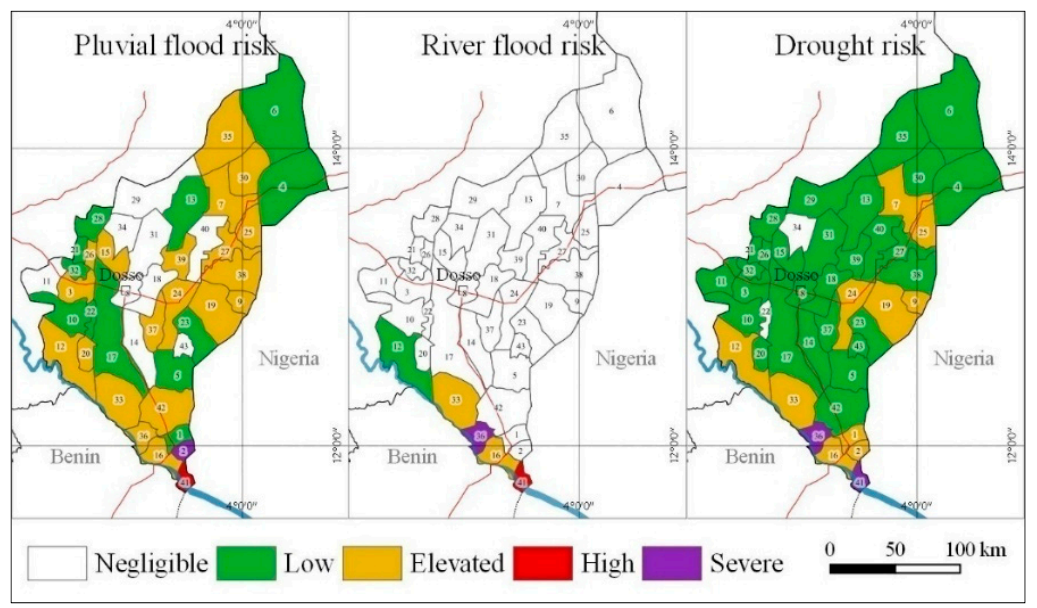

Figure 11. Pluvial flood (left), fluvial flood (center), and drought (right) risk levels from 2011 to 2017 in the Dosso region using data from Table 4.

The MHRI is obtained by summing the pluvial flood, fluvial flood, and drought risk indices. In this case, a risk level higher than 3 indicates that the municipality concerned has a risk that is higher than its demographic weight in the region. The level of risk is severe in the municipalities of Bengou (dallol) and Tounouga (River Niger), high at Tanda (River Niger), and elevated in another 
12 municipalities, particularly in the dallols (Guilladje, Doumega, KarguiBangou) and along the river (Gaya). The risk is low in 27 municipalities and negligible or absent in one of them (Figure 12, Table 4).

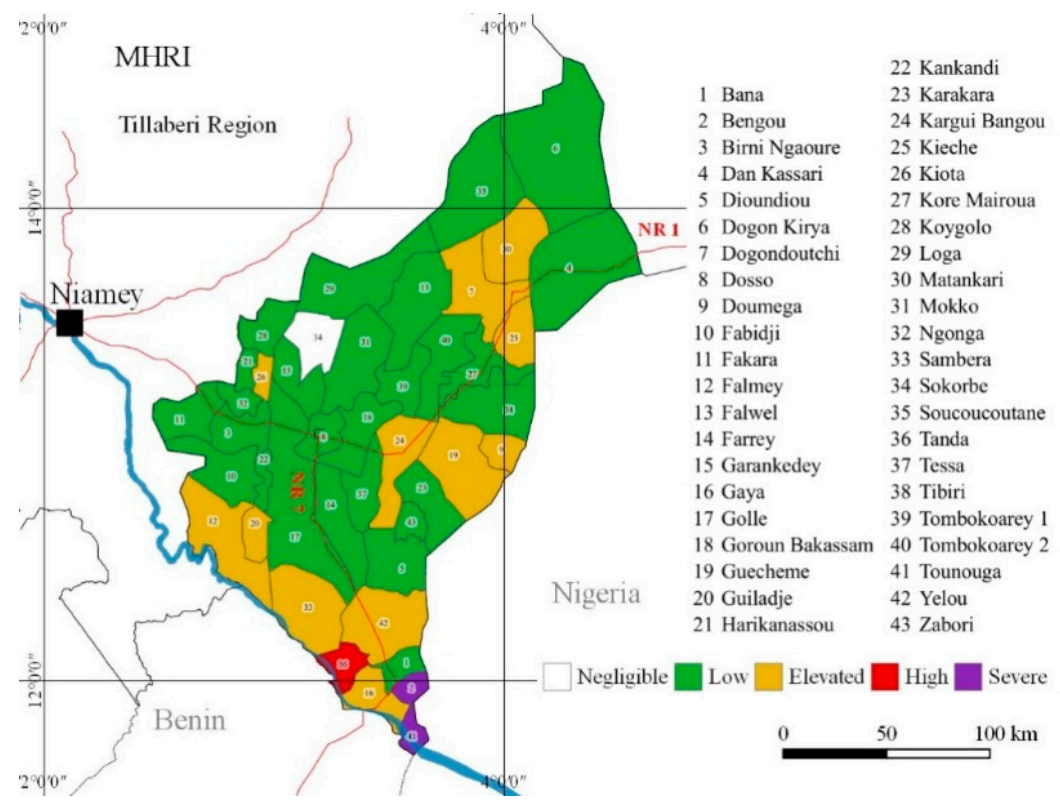

Figure 12. Multihazard risk at the municipal scale in the Dosso region, 2011-2017 using data from Table 4 .

\subsection{The Potential Use of Risk Assessment: Planning with Climate}

The potential use of risk assessment becomes clear when comparing the principal risk, determinant, and indicator and the MHRI to the actions developed by plans and projects, their budget for action implementation, and the number of municipalities where they are implemented.

\subsubsection{The Consistency between Actions and the Principal Risk, Determinant, and Indicator}

Fluvial flooding, L\&D, and flooded fields are the risk, the determinant, and the indicator, respectively, that influence the MHRI the most. Unfortunately, neither the MDPs nor the adaptation and resilience projects envisage antiflooding actions aimed at reducing L\&D or the use of embankments to protect fields from flooding.

In Tounouga, which has been hit several times by fluvial and pluvial flooding, actions focus on reducing the impact of drought. In Tanda, which has been hit several times by fluvial flooding, actions focus on reducing runoff and drought. In contrast, in Doumega, hit by drought and pluvial flooding, actions are well planned and focus on water and soil conservation (WSC) and gardens. The same is true for Dogondoutchi, Falmey, and Guéchémé, hit by pluvial flooding, where the main actions consist in reducing runoff, planting trees, reinforcing the banks of creeks, and improving storm water drainage. Nevertheless, not one single municipality has planned either awareness campaigns or the monitoring of rainfall at a local level.

\subsubsection{The Consistency between the Budget for Actions and the MHRI Level}

Many large-scale actions should be put in place if we hope to reduce risk. Unfortunately, the quota of the total budget of the six MDPs set aside for CC adaptation actions is inversely proportional to the MHRI level: very low in municipalities at severe risk (0.5-1.3\%) and high in those considered to be at elevated risk (8.4-22.6\%) (Table 5). 
Table 5. The budget for pro-climate actions scheduled by six MDPs (figures expressed in thousands of USD).

\begin{tabular}{|c|c|c|c|c|c|c|}
\hline & \multicolumn{6}{|c|}{ Municipality } \\
\hline & Tounouga & Tanda & Douméga & Guéchémé & Dogondoutchi & Falmey \\
\hline Hazard * & $\mathrm{PF}$ & $\mathrm{PF}$ & DF & $\mathrm{F}$ & $\mathrm{F}$ & $\mathrm{F}$ \\
\hline MHRI & 36 & 28 & 9 & 6 & 4 & 3 \\
\hline Actions: & & & & & & \\
\hline Training & & & & & 1 & \\
\hline OSV-SCAPRU & & & & 29 & 1 & \\
\hline WSC & & 58 & & 550 & 545 & 507 \\
\hline Treeplanting & & & 75 & 81 & 8 & 4 \\
\hline Stoves & & & 18 & & & \\
\hline Culverts & & & & 64 & & \\
\hline Creeks & & & & 190 & & \\
\hline Drainage & & & & & 28 & \\
\hline Weir & & & & 319 & & \\
\hline Latrines & & & & & & 49 \\
\hline Seeds & & & & & 4 & \\
\hline Gardens & & 86 & 120 & 214 & 23 & \\
\hline Imputbank & 11 & 28 & 26 & & 8 & \\
\hline Cerealbank & 11 & 47 & 73 & & 19 & \\
\hline
\end{tabular}

\subsubsection{The Consistency between the Number of Projects and the MHRI Level}

A third potential use of the MHRI involves verifying how consistent the number of projects and the MHRI level are in each municipality. Twenty-three municipalities benefit from risk reduction, adaptation, and resilience actions put in place by 12 projects. The appraisal, midterm, and final evaluation reports of risk reduction, adaptation, and resilience projects allow us to identify which municipalities boast actions that have been completed or are envisaged for the future and to compare their distribution with the multihazard risk index (Table 6). If we group municipal projects according to their risk classes, we notice that their geographical distribution does not reflect the MHRI level: we find 1 project per municipality considered to be at severe risk, no projects in municipalities at high risk, 0.9 projects per municipality at elevated risk, 0.8 for those at low risk, and 3 projects in municipalities at negligible risk (Figure 13, Table 6). 


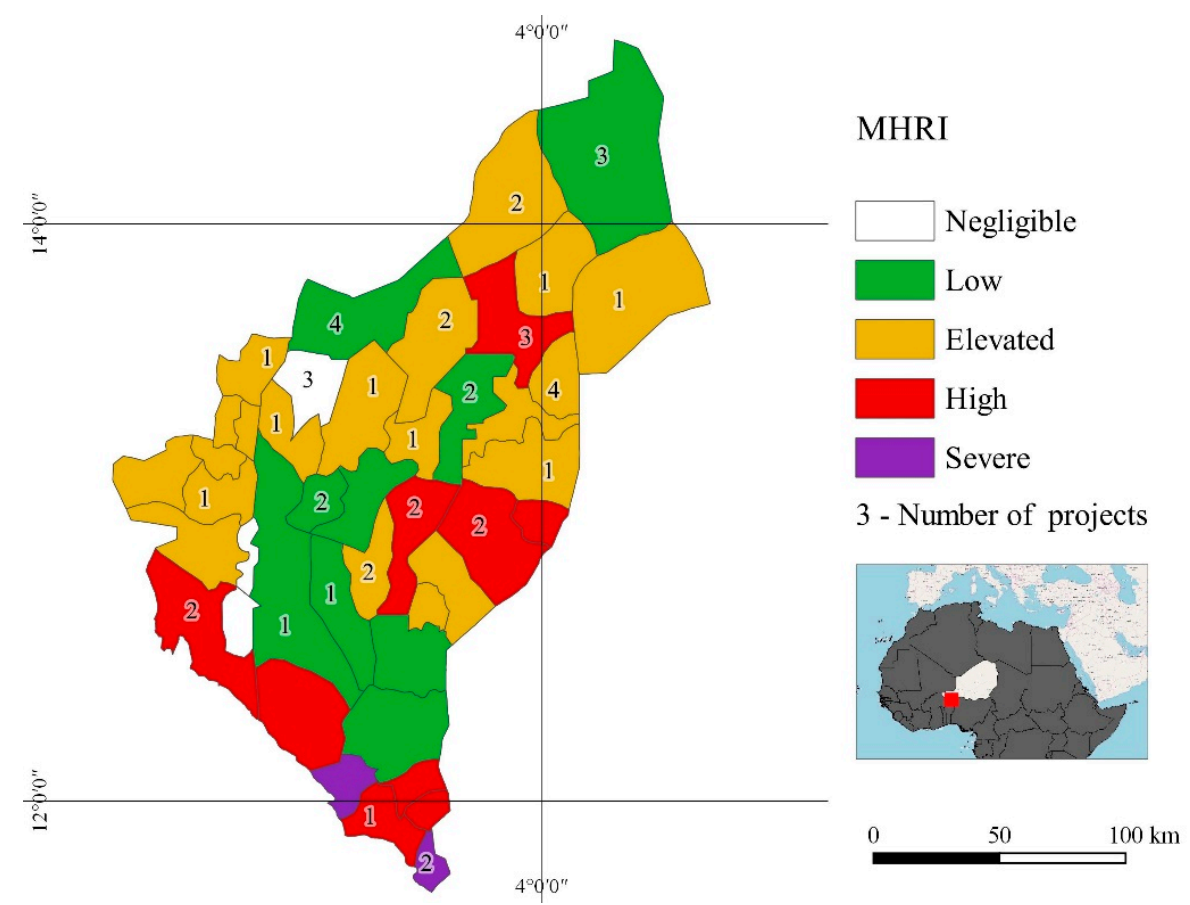

Figure 13. Multihazard risk level and the number of adaptation projects in municipalities of the Dosso region according data from Table 6. 
Table 6. Municipalities benefiting from risk, adaptation, or resilience actions according 12 projects and MHRI.

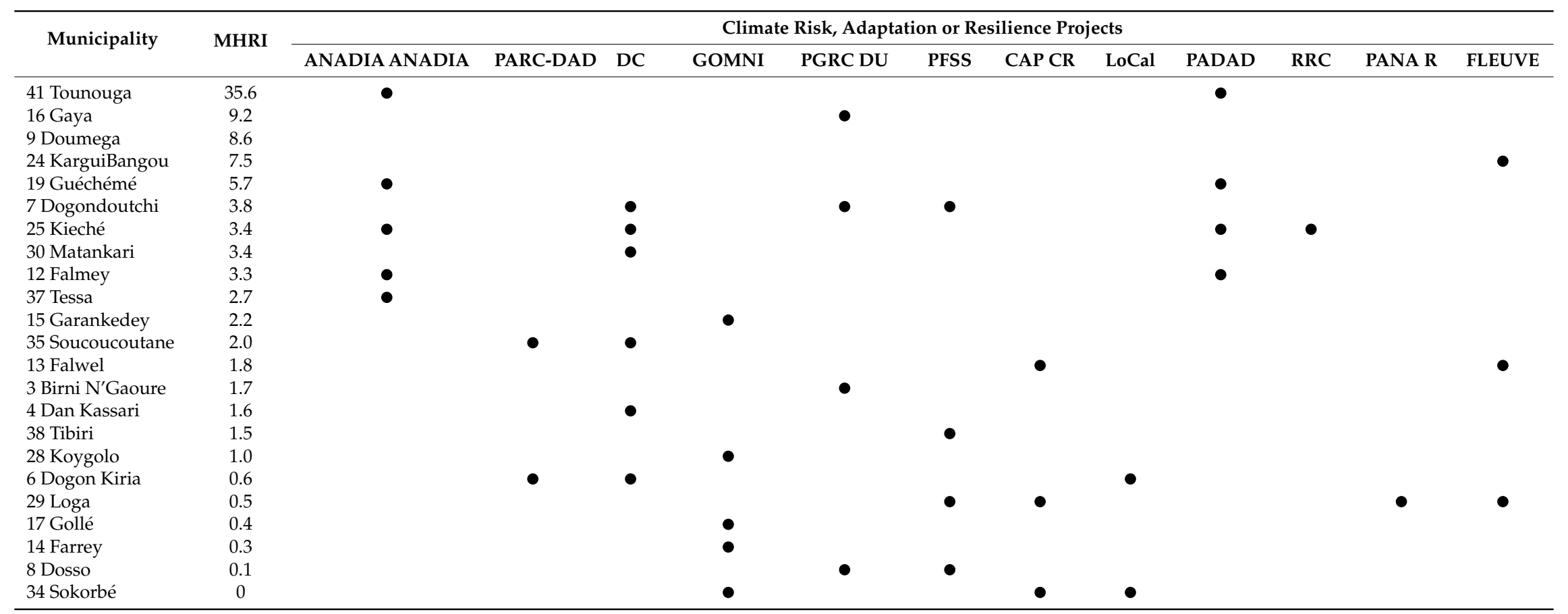

ANADIA 2.0-Adaptation au changement climatique, prevention des catastrophes et développement agricole pour la sécurité alimentaire, 2017-2020; CAP-CR-Community Action Project for ClimateResilience, 2013-2018; DC-Doutchi-Climat, 2017-2019; FLEUVE-Front Local Environnement pour une Union Verte, GOMNI-2017-2019; LoCAL-Mécanisme financement Adaptation au Changement Climatique au niveau Local, 2015-2016; PADAD-Programme d'Appui Développement Agricole Dosso, 2014-2016; PANA-R-Programme d'Action National pour l'Adaptation-Résilience, 2010-2014; PGRC-DU-Projet de Gestion des Risques de Catastrophe et de Développement Urbain, 2013-2019; PARC-DAD-Projet d'appui à la Résilience Climatique pour un Développement Agricole Durable, 2015-2020; PASEC-Projet d'Appui à l'Agriculture Sensible aux Risques Climatiques, 2016-2022; PFSS-Projet Filets de Securité Sociale, 2011-2019; RRC-Renforcement de la Resilience Communautaire, 2014-2016. 


\subsubsection{The Consistency between Categories of Actions and the MHRI Level}

A fourth way of using the assessment is to evaluate the level to which the categories of actions envisaged by projects are consistent with the MHRI. Projects usually focus on improving practices/behaviors (mainly WSC, seed selection, land restoration, and improved stoves) and infrastructure (irrigation and pastoral wells). Planning (risk reduction taken into account in MDPs, livelihood diversification) is less common. Information (rain gauges), warnings (bulletins, weather/hydro services), and capacity building (best practice data, etc.) are even less common. Financing (insurance, microfinancing, contingency funds for disasters) and technology (solar energy capacity, biogas) that reduces deforestation and, as a result, runoff, are entirely absent. Only 3 out of the 15 municipalities at severe and elevated multihazard risk are gathering, or have gathered, information or early warning data regarding potentially disastrous hydroclimatic events, adaptation practices and behavior, or disaster-protection infrastructure (Table 7), though five envisage it.

Table 7. The number of adaptation actions developed by 12 projects in each municipality grouped according the categories proposed by [84] and compared with the level of multihazard risk.

\begin{tabular}{|c|c|c|c|c|c|c|c|c|}
\hline \multirow{2}{*}{ Municipality } & \multirow{2}{*}{ MHRI } & \multicolumn{7}{|c|}{ Category } \\
\hline & & A & B & $\mathrm{C}$ & D & $\mathrm{E}$ & $\mathbf{F}$ & G \\
\hline 41 Tounouga & 35.6 & & 2 & & 1 & 1 & 1 & \\
\hline 16 Gaya & 9.2 & 1 & 1 & 1 & & & & \\
\hline 24 KarguiBangou & 7.5 & 1 & & 5 & & 2 & & \\
\hline 19 Guéchémé & 5.7 & & 2 & & 1 & 1 & 1 & \\
\hline 7 Dogondoutchi & 3.8 & 3 & 2 & 4 & & 2 & & 1 \\
\hline 25 Kieché & 3.4 & 1 & 5 & 3 & 1 & 6 & 1 & 1 \\
\hline 30 Matankari & 3.4 & 2 & 2 & 2 & & 2 & & 1 \\
\hline 12 Falmey & 3.3 & & 2 & & 1 & 1 & 1 & \\
\hline 37 Tessa & 2.7 & 1 & 1 & 3 & 1 & 2 & 1 & \\
\hline 15 Garankedey & 2.2 & & & 1 & & & & \\
\hline 39 TomboKoarey I & 2.1 & 1 & & 2 & & 2 & & \\
\hline 35 Soucoucoutane & 2.0 & 2 & 2 & 2 & & 2 & & 1 \\
\hline 13 Falwel & 1.8 & 1 & 1 & 4 & & & & \\
\hline 31 Mokko & 1.7 & 1 & & 2 & & 2 & & \\
\hline 4 Dan Kassari & 1.6 & 1 & 2 & 2 & & 2 & & 1 \\
\hline 38 Tibiri & 1.5 & & & 1 & & & & 1 \\
\hline 28 Koygolo & 1.0 & & & 1 & & & & \\
\hline 3 Birni N'Gaoure & 0.9 & & 1 & & & & & \\
\hline 6 Dogon Kiria & 0.6 & 2 & 2 & 4 & & 2 & 1 & 1 \\
\hline 29 Loga & 0.5 & 2 & 1 & 6 & & 3 & & 1 \\
\hline 40 TK II-Sakadamna & 0.5 & 1 & & 5 & & 2 & & \\
\hline 17 Gollé & 0.4 & & & 1 & & & & \\
\hline 14 Farrey & 0.3 & & & 1 & & & & \\
\hline 8 Dosso & 0.1 & & & 1 & & & & 1 \\
\hline 34 Sokorbé & 0 & 1 & 1 & 3 & & & & \\
\hline Sum & & 21 & 27 & 54 & 5 & 32 & 6 & 9 \\
\hline
\end{tabular}

A, Capacity building (best practices, study trip); B, Management and planning (pond fish training, RR plans, CC integration into LDPs); C, Practices and behavior (WSC, selected seeds, improved stoves); D, Information on climate change (local rainfall monitoring); E, Infrastructure (irrigation, pastoral wells); F, Warning (agro-meteo bulletin); G, Green infrastructure (village nursery).

\subsubsection{The Consistency between Actions and Factors that Cause Disasters}

None of the six MDPs taken into consideration envisage actions that directly affect factors that cause hydroclimatic disasters. As far as projects are concerned, $56 \%$ of the municipalities in the Dosso region are running actions that affect factors that contribute to drought impact (rain gauges, short-cycle cultivars). 


\subsection{Uncertainties}

The uncertainties intrinsic to the MHRI depend on the amount of information we have at our disposal. Compared to the optimum density of weather stations, one every $100 \mathrm{~km}^{2}$, in this case, just one weather station per municipality would be ideal (100\%). Information regarding the number of inhabitants and the amount of L\&D (cereal deficit) following disasters should be available for every place hit by disaster $(100 \%)$. In practice, though, this kind of information is available for a lower percentage (Table 8$)$.

Table 8. Information coverage.

\begin{tabular}{lccc}
\hline Hazard & $\begin{array}{c}\text { Municipalities Provided with a } \\
\text { Weather Station Having 30 Years } \\
\text { of Rain Registrations }\end{array}$ & $\begin{array}{c}\text { Settlements Providing } \\
\text { the Amount of } \\
\text { Population }\end{array}$ & $\begin{array}{c}\text { Settlements Providing } \\
\text { the Quantity and Type } \\
\text { of Loss and Damage }\end{array}$ \\
\hline & $\%$ & $\%$ & $\%$ \\
Pluvial flood & 47 & 74 & 74 \\
Fluvial flood & - & 99 & 99 \\
Meteorological drought & 47 & 89 & 89 \\
\hline
\end{tabular}

Data regarding rainfall is the most sensitive. In large municipalities, critical rainfall can change from one zone to the next, but the variability of hazards ranges from 0 to 1 , and therefore has a limited effect on the level of risk. Generally speaking, due to this lack of information, the risk in municipalities is underestimated.

\section{Discussion}

This assessment takes its cue from the statement that CC adaptation plan and project development in West Africa cannot yet base itself on local hydroclimatic risk mapping and on decision-making-oriented analyses. The main problem that needs tackling is therefore how to organize a multihazard risk assessment at a regional scale that will be useful during decision-making processes.

The first issue concerned climate characterization at the regional scale. Using the CHIRPS daily dataset, it proved possible to calculate trends in extreme events, extremely heavy precipitation days, and dry spells for the centroid of each municipality over the past seven years, comparing them to the previous 30 years. This characterization helps to explain why a region hit by droughts between 2011 and 2017 in the same period is affected by red floods of the River Niger higher than the previous 30 years. This paradox is explained by the analysis of extreme rainfall, the increased frequency of which contributes (accompanied by other factors) to an increased runoff and confirms, also for the Dosso region, a more general trend observed in West Africa [91].

The second issue was how to indicate risk level. The assessment forgoes using pixels as a typical unit of representation in the spatial analyses carried out up to now in West Africa at a regional scale, preferring municipal jurisdiction [38,92]. Unable to monetarily quantify risk, the reference to a municipality's demographic weight in the region makes it easier to understand the risk level.

The third issue was how to link the climate characterization and risk-level figures to recommendations that could be useful when developing plans and projects, an aspect that rarely $[17,39,51]$ had been tackled by previous risk analyses. The increased frequency of extreme rainfall events in the municipalities of BirniN'Gaoure, Dan Kassari, Dogon Kiria, Loga, Matankari, $\mathrm{N}^{\prime}$ Gonga, and Soucoucoutane means that receptors must be protected. More frequent heavy rains justify WSC and storm water drainage. Nevertheless, L\&D are also caused by the impact of heavy rains on buildings made of fragile materials and the impact on wells, fountains, and latrines at ground level, which are flooded and remain out of bounds for the entire rainy season. The assessment raises the question of a general improvement of the habitat by, for example, replacing mud roofs with corrugated iron and raising the level of the foundations of homes and the bases of wells, fountains, and latrines. Higher river flooding and the predominance of red floods as opposed to Guinean floods 
require the protection of rain-fed crops during the rainy season and early warning systems to store equipment and livestock in a safe place during floods. The higher number of dry spells that last longer in the municipalities of BirniN'Gaoure, Dosso, Fakara, Farrey, Garankedey, Golle, GoroubanKassam, Harikanassou, Kiota, Koyogolo, N'Gonga, Sokorbe, Soucoucoutane, and Tessa require greater attention when monitoring rainfall locally and, in particular, the adoption of adaptation strategies, such as the introduction of drought-resistant cultivars, crop diversification, changes in cropping patterns and sowing dates, as well as improved WSC to manage soil moisture.

To date, local rainfall monitoring, warnings (weather and crop bulletins), and green infrastructures (village forestation) have rarely been used in adaptation and resilience projects for the Dosso region. Over the past 20 years, aid projects in Niger have focused on food security in an area where most of the regions are affected by drought and continue to be so. Three-fourths of projects usually operate in more than one region and extend the same actions to all areas of intervention, including wetter regions like Dosso, which explains the inconsistencies.

The fourth issue concerned the extension of the assessment to other regions and its repetition over time: the weakness of previous studies. The use of information regularly gathered by public bodies at a national scale and available at the settlement and municipality level, combined with simple calculation methods, allow personnel lacking advanced skills to carry out risk tracking in any region.

We have learned two main lessons from this assessment.

The first lesson learnt is that vulnerability indicators should take their cue from an understanding of the factors that turn a local hydroclimatic event into a disaster and not from easily accessible information or field literature. Should information be lacking, it is best to resort to L\&D, if available [93].

The second lesson learnt is that methods that use low-resolution DEM and satellite images to identify flood-prone areas are inadequate. If we were to apply the buffer technique or DEM to identify areas prone to flooding along the River Niger and the dallols, we would end up with an overestimation: over the past seven years, only $29 \%$ of the settlements along the River Niger, and just $20 \%$ of those in the dallols, have ever been flooded.

Three unexpected results emerged from our work.

The first unexpected result was the lack of coverage provided by global, open-access databases regarding flooding and drought compared to national ones. The former record only $18-44 \%$ of the events listed in national databases and have proved to be particularly unreliable when it comes to drought.

The second unexpected result of the assessment were the 121 settlements prone to multihazards (flooding and drought) scattered over no fewer than 31 municipalities. The small number of settlements repeatedly hit by floods and droughts opens at least two issues for development policies that should be ascertained. First of all, if flooding can also be an opportunity not just a disaster, for example, by encouraging flood recessional cropping in areas where it was previously impossible to do so [94,95]. Secondly, if floods and droughts trigger temporary or permanent migratory processes in the locations repeatedly hit: an aspect that is beginning to be studied in West Africa [96].

The third unexpected result was the concentration of L\&D due to fluvial flooding in a handful of municipalities, which produces high levels of risk compared to a situation where it is more generally distributed (drought). This is an important consideration for adaptation actions that, up to now, have rarely addressed this threat.

The shortcomings of the assessment include the use of incomplete information (L\&D). This results in an underestimation of the risk level in some municipalities. The origin of flooding in the single settlements that have been hit (watershed surge, flash floods, ponds, the impact of extreme rains on receptors) is still unknown. The origin of drought is clearer but its level is not specified for all settlements. An initial improvement would be to include such information in the assessment.

A second improvement would be to financially quantify L\&D, which would be possible if surveys specified the types of buildings and crops affected. This would allow us to include a level of 
evaluation in the assessment, i.e., to calculate the cost-effectiveness of risk reduction and adaptation in municipalities.

A third improvement would be to include local climate scenarios. The use of various different medium- and long-term climate forecasts would allow us to assess the future evolution of extreme events in the Dosso region and therefore characterize the hazard component of future risk. In this way, the planning process would be based on more concrete climate models.

The assessment ends by making four recommendations.

The first is addressed to the Ministry of Humanitarian Action and Disaster Management and concerns the completion and extension of information regarding flooding to ensure that the geographic coordinates of the places hit are always specified, as well as the origin of the flooding, the type and size of buildings hit, and the type of crops affected. This will allow us to improve the analysis and complete our assessment with an evaluation.

The second recommendation is addressed to the Ministry of Agriculture and Livestock, so that it may systematically specify the causes and extent of cereal deficit in all settlements, possibly linking this information to agrometeorological information such as the sowing date, types of crops, and the use of any water management techniques. This would allow us to improve our calculation of the drought risk level.

The third recommendation is addressed to the Ministry for Community Development and Territorial Planning and to the Directorates Regional, so that they may consider risk assessment and make it open access, updating it every few years, using it in Regional Development Plans, and requiring it to be included in MDPs.

The fourth and final recommendation is addressed to international aid organizations, so that they may consider risk assessment in identification and evaluation phases, since CC and hydroclimatic disasters could influence the impact of projects.

\section{Conclusions}

The number of CC adaptation plans and projects in West Africa is not keeping pace with our understanding of the climate and hydroclimatic risk at a regional level.

This article is unlike those that preceded it because it characterizes climate at a local level, it identifies the settlements at risk, it uses local sources in order to get L\&D information that is more precise than the data found in global open-access databases, it analyzes risk determinants one at a time, and ranks multihazard risk using municipal jurisdiction as a minimal information unit. Its potential uses have been identified for the Dosso region (Niger).

Local planning requires high-resolution climate analysis in order to monitor the dynamics of extreme phenomena. Should a dense network of weather stations be lacking, a recurring situation in West Africa, we can combine the analysis with high-resolution rain estimate datasets. This allows us to measure hazard at a municipal scale more accurately.

Although $28 \%$ of localities and $67 \%$ of the population of Dosso have been hit by flooding or drought over the past seven years, in actual fact, 606 settlements (12\% of the regional total) have been hit more than once. Therefore, there are fewer hot spots, which are geographically concentrated along the River Niger and in the dallols.

The importance of having a holistic vision of risk, as recommended by the Sendai Framework, is confirmed if we consider the 121 settlements exposed to multihazards ( 38 of which in the same year, see Table S3), the distribution of CC adaptation projects that do not reflect the risk level, and MDPs with actions that do not address the main threats.

This assessment lists the places that have been repeatedly hit by flooding and drought and the municipalities that are most at risk but do not benefit from adaptation actions, as well as the types of measures that address hazards but are as yet lacking.

The use of L\&D information collected on a regular basis by national bodies and the ease with which we calculate risk make the assessment applicable to other regions of Niger, as well as other countries. 
The assessment is based on previous knowledge. Future improvements should include more complete data when this will be available and CC scenarios (an increase in heavy rainfall, drought) in the risk level.

Supplementary Materials: The following are available online at http:/ /www.mdpi.com/2225-1154/6/3/67/s1, Table S1: Equations, Table S2: SPI 1981-2017 for the municipalities of the Dosso region (Niger), Table S3: Disaster frequency in the Dosso region (Niger) according municipality and settlement, 2011-2117.

Author Contributions: M.T. conceived the paper's concept and developed Section 1, Section 4, and Section 5, Sections 3.4-3.6. M.B. developed Sections 2.3 and 3.1 and its respective figures. S.B. developed Section 3.2, the spatial analysis, and the remaining figures. Section 3.3 was developed jointly by the three authors.

Funding: This research was funded by the ANADIA-Niger Project (Adaptation to climate change, disaster prevention and agricultural development for food security) by the Italian Agency for Development Cooperation, the Institute of Biometeorology of the National Research Council of Italy, the Interuniversity Department of Regional and Urban Studies and Planning of the Politecnico and University of Turin and the Directorate National for Meteorology of Niger.

Acknowledgments: The authors would like to thank the Italian Agency for Development Cooperation for supporting the ANADIA 2.0 project and the actions that allowed the development of this assessment. We are thankful to Vieri Tarchiani (Ibimet CNR) for supporting field activities. We would like to express our deepest gratitude to Edoardo Fiorillo (Ibimet CNR), Gaptia Lawan Katiellou (Directorate National for Meteorology), Mohamed Housseini Ibrahim (Directorate for Hydraulics, Ministry of Hydraulics and Sanitation), Moumouni Tankari (Directorate for Agriculture Statistics), Hassimou Issa (Coordination unit/EWS), Moussa Ali and Mamane Souley Maïnassara (Dosso Directorate Regional for Community Development and Territorial Planning) and the personnel of the Dosso Directorate for Environment for having shared data and information with us.

Conflicts of Interest: The authors declare no conflict of interest.

\section{References and Notes}

1. United Nations General Assembly. Sendai Framework for Disaster Risk Reduction 2015-2030; UNISDR: Geneva, Switzerland, 2015; Available online: https:/ /www.unisdr.org/files/43291_sendaiframeworkfordrren. pdf (accessed on 18 March 2018).

2. United Nations. The Sustainable Development Goals. 2015. Available online: http://www.un.org/ sustainabledevelopment/sustainable-development-goals / (accessed on 18 March 2018).

3. De Moel, H.; Jongman, B.; Kreicich, H.; Merz, B.; Penning-Roswell, E.; Ward, P.J. Flood Risk Assessment at Different Spatial Scales. Mitig. Adapt. Strateg. Glob. 2015, 20, 866-890. [CrossRef]

4. Murnane, R.; Simpson, A.; Jongman, B. Understanding risk: What makes a risk assessment successful? Int. J. Disaster Resil. Built Environ. 2015, 7, 186-200. [CrossRef]

5. United Nations Office for Disaster Risk Reduction. Terminology on Disaster Risk Reduction; UNISDR: Geneva, Switzerland, 2009.

6. Tiepolo, M. Relevance and quality of Climate planning for large and medium-sized cities of the Tropics. In Renewing Local Planning to Face Climate Change in the Tropics; Tiepolo, M., Pezzoli, A., Tarchiani, V., Eds.; Springer: Cham, Switzerland, 2017; pp. 199-226.

7. Barrantes, G. Multi-hazard model for developing countries. Nat. Hazards 2018, 92, 1081-1095. [CrossRef]

8. Bernal, G.A.; Salgado-Gálvez, M.A.; Zuloaga, D.; Tristancho, J.; González, D.; Cardona, O.-D. Integration of probabilistic and multi-hazard risk assessment within urban development planning and emergency preparedness and response: Application to Manizales, Colombia. Int. J. Disaster Risk Sci. 2017, 8, 203-270. [CrossRef]

9. Mulyani, R.; Ahmadi, R.; Pilakoutas, K.; Hajirasouliha, I.; Taufik. A multi-hazard risk assessment of buildings in Padang city. Procedia Eng. 2015, 125, 1094-1100. [CrossRef]

10. Ponte, E. Flood risk due to heavy rains and rising sea levels rise in the municipality of Maputo. In Climate Change Vulnerability in Southern African Cities. Building Knowledge for Adaptation; Macchi, S., Tiepolo, M., Eds.; Springer: Cham, Switzerland, 2014; pp. 187-204. ISBN 978-3-319-00672-7.

11. UNDP. Hazard Risk and Vulnerability Analysis (HRVA) of the City of BHUBANESWAR (Odisha); Final Report; UNDP: New York, NY, USA, 2014.

12. Kaur, H.; Gupta, S.; Parkash, S.; Thapa, R. Application of geospatial technologies for multi-hazard mapping and characterization of risk at local scale. Ann. GIS 2018, 24, 33-46. [CrossRef] 
13. Van Westen, C.J.; Montoya, L.; Boerboom, L. Multi-hazard Risk Assessment Using GIS in Urban Areas: A Case Study for the City of Turrialba, Costa Rica. In Proceedings of the Hazard Mapping and Risk Assessment Regional Workshop, Bali, Indonesia, 24-26 September 2002.

14. Wannewitz, S.; Hagenlocher, M.; Garschagen, M. Development and validation of a sub-national multi-hazard risk index for the Philippines. GI Forum 2016, 1, 133-140. [CrossRef]

15. Petrie, B.; Chapman, A.; Midgley, A.; Parker, R. Vulnerability and resilience in the Limpopo river basin system: Climate change, water and biodiversity. A synthesis. Cape Town, One World, 2014; unpublished.

16. Varazanashvili, O.; Tsereteli, N.; Amiranashvili, A.; Tsereteli, E.; Elizbarashvili, E.; Dolidze, J. Vulnerability, hazards and multiple risk assessment for Georgia. Nat. Hazards 2012, 64, 2012-2056. [CrossRef]

17. Wipulanusat, W.; Nakrod, S.; Prabnarong, P. Multi-hazard risk assessment using GIS and RS applications: A case study of Pak Phanang basin. Walailak J. Sci. Technol. 2009, 6, 109-125.

18. Thierry, P.; Stieltjes, L.; Kouokam, E.; Nguéya, P.; Salley, P.M. Multi-hazard risk mapping and assessment on an active volcano: The GRINP project at Mount Cameroon. Nat. Hazards 2008, 45, 429-456. [CrossRef]

19. Papathoma-Köhle, M.; Promper, C.; Glade, T. A common methodology for risk assessment and mapping of climate change related hazards-implications for climate change adaptation policies. Climate 2016, 4, 8. [CrossRef]

20. Marzocchi, W.; Garcia-Aristizabal, A.; Gasparini, P.; Mastellone, M.; Di Ruocco, A.; Novelli, P. Basic principles of multi-riskassessment: A case study in Italy. Nat. Hazards 2012, 62, 551-573. [CrossRef]

21. Grünthal, G.; Thieken, A.; Schwartz, J.; Smolka, A.; Mertz, B. Comparative risk assessment for the city of Cologne-storms, floods, earthquakes. Nat. Hazards 2006, 38, 21-44. [CrossRef]

22. Greiving, S.; Fleischhauer, M.; Lückenkötter, J. A methodology for an integrated risk assessment of spatially relevant hazards. J. Environ. Plan. Man 2006, 49, 1-19. [CrossRef]

23. Granger, K.; Jones, T.; Leiba, M.; Scott, G. Community risk in Cairns: A multi-hazard risk assessment. Aust. J. Emerg. Manag. 1999, 14, 29-30.

24. Niang, I.; Ruppel, O.C.; Abdrobo, M.A.; Essel, A.; Lennard, C.; Padgam, J.; Urguhart, P. Africa. In Climate Change 2014: Impacts, Adaptation, and Vulnerability. Part B: Regional Aspects, Contribution of the WG II to the Fifth Assessment Report of the IPCC; Cambridge University Press: Cambridge, UK, 2014; pp. 1199-1265. Available online: http:/ / www.ipcc.ch/report/ar5/wg2/ (accessed on 18 March 2018).

25. Nicholson, S.E. Climatic and environmental change in Africa during the last two centuries. Clim. Res. 2001, 17, 123-144. [CrossRef]

26. Nicholson, S. On the question of the 'recovery' of the rains in the West African Sahel. J. Arid Environ. 2005, 63, 615-641. [CrossRef]

27. Panthou, G.; Vischela, T.; Lebel, T. Short communication Recent trends in the regime of extreme rainfall in the Central Sahel. Int. J. Climatol. 2014, 34, 3998-4006. [CrossRef]

28. Tschakert, P.; Sagoe, R.; Ofori-Darko, R.; Codjoe, S. Floods in the Sahel: An analysis of anomalies, memory, and anticipatory learning. Clim. Chang. 2010, 103, 471-502. [CrossRef]

29. Ceccherini, G.; Russo, S.; Ameztoy, I.; Marchese, A.F.; Carmona-Moreno, C. Heat waves in Africa 1981-2015, observations and reanalysis. Nat. Hazard Earth Syst. 2017, 17, 115-125. [CrossRef]

30. CRED. EM-DAT: The Emergency Events Database-Universitécatholique de Louvain (UCL). D. Guha-Sapir, Brussels. Available online: www.emdat.be (accessed on 12 March 2018).

31. Roudier, P.; Sultan, B.; Quirion, P.; Berg, A. The impact of future climate change on West African crop yields: What does the recent literature say? Glob. Environ. Chang. 2011, 21, 1073-1083. [CrossRef]

32. OECD. Climate Change: OECD External Development Finance Statistics. Available online: http://www. oecd.org/dac/financing-sustainable-development/development-finance-topics/climate-change.htm (accessed on 1 March 2018).

33. Van Niekerk, D. Disaster performance in Africa. A retrospective assessment of progress in against the hyogo framework for action (2000-2012). Disaster Prev. Manag. 2015, 24, 397-426. [CrossRef]

34. Adelikan, I.; Johnson, C.; Manda, M.; Matyas, D.; Mberu, B.U.; Parnell, S.; Pelling, M.; Satterthwaite, D.; Vivekanada, J. Disaster risk and its reduction: An agenda for urban Africa. Int. Dev. Plan. Rev. 2015, 37, 33-40. [CrossRef]

35. Plan National de Contingence Multirisques du Togo. Cinquième edition mai 2015-mai 2016. 2015. Available online: http: / / securite.gouv.tg/sites / default/ files / documents / plan_national_de_contingence_version_ 2015.pdf (accessed on 18 March 2018). 
36. Direction Nationale de la Protection Civile du Mali. Etude des Inondations au Mali 2006-2013; UNICEF: Geneva, Switzerland, 2014; Available online: http:/ / www.reachresourcecentre.info/system/files/resourcedocuments/anne.thurin-08052014-024644-REACH_\%20Etude\%20des\%20Inondations\%20au\%20Mali\% 202006-2013.pdf (accessed on 18 March 2018).

37. Gouvernement du Burkina Faso. Plan National Multi Risque de Preparation et de Reponse aux Catastrophes. Available online: http:/ / www.ifrc.org/docs/IDRL/burkinafasoPlan.pdf (accessed on 18 March 2018).

38. R. of N. Plan National de Contingence Multi Risque Niger 2013. SAP/PC. 2013. Available online: http:/ / www.ne.undp.org/content/dam/niger/docs/Publications/UNDP-NE-PLAN-NATIONALCONTINGENCE2013.pdf (accessed on 18 March 2018).

39. Asare-Kyei, D.; Renaud, F.G.; Kloos, J.; Walz, Y.; Rhyner, J. Development and validation of risk profiles of West African rural communities facing multiple natural hazards. PLoS ONE 2017, 12, e0171921. [CrossRef] [PubMed]

40. Mayomi, I.; Dami, A.; Maryah, U.M. GIS based assessment of flood risk and vulnerability of communities in the Benoue floodplains, Adamawa State, Nigeria. J. Geogr. Geol. 2013, 4, 148-160.

41. Natajal, J.; Lamptey, L.B.; Mahamadou, I.B.; Nyarko, B.K. Flood disaster risk mapping in the lower Mono river basin in Togo, West Africa. Int. J. Dis. Risk Res. 2017, 13, 93-103. [CrossRef]

42. Ekere, O.O.; Udoh, J.O. Multi hazard risk assessment using GIS techniques in the Mbo area of Nigeria. Asian Rev. Environ. Earth Sci. 2014, 1, 1-4.

43. N'guessan Bi, V.H.; Saley, B.; Wade, S.; Valere, D.E.; Kouame, F.; Affian, K. Cartographie du risque d'inondation par une approche couplée de la télédétection et des systèmes d'information géographiques (SIG) dans le département de Sinfra (Centre-ouest de la Cote d'Ivoire). Eur. Sci. J. 2014, 10, 170-191.

44. Danumah, J.H.; Odai, S.N.; Saley, B.M.; Szarzynski, J.; Thiel, M.; Kouame, A.; You Akpa, L. Flood risk assessment and mapping in Abidjan district using multi-criteria analysis (AHP) model and geoinformation techniques (Cote d'Ivoire). Geoenviron. Dis. 2016, 3, 10. [CrossRef]

45. Oriola, E.; Chibuike, C. Flood risk analysis of the Edu government area (Kwara state, Nigeria). Geogr. Environ. Sustain. 2016, 3, 106-116. [CrossRef]

46. Koudamiloro, O.; Vissin, E.W.; Sintondji, L.O.; Houssou, C.S. Effets Socio-Économiques et Environnementaux des Risques Hydroclimatiques Dans le Bassin Versant du Fleuve Ouémé à L'exutoire de Bétérou au Benin (Afrique de l'Ouest); XXVIIIe Colloque de l'Association Internationale de Climatologie. Liège, Belgium, 2015; pp. 543-548. Available online: www.climato.be/aic/colloques/actes/ACTES_AIC2015/5\%20Variabilites\%20et\%20aleas\% 20climatiques /088-KOUDAMILORO-543-548.pdf (accessed on 18 March 2018).

47. Behanzin, I.D.; Thiel, M.; Szarzynski, J.; Boko, M. GIS-based mapping of flood vulnerability and risk in the Benin Niger river valley. Int. J. Geomat. Geosci. 2015, 6, 1653-1669.

48. Saley, M.B.; Kouamé, F.K.; Penven, M.J.; Biémi, J.; Boyssoro Kouadio, H. Cartographie des zones à risque d'inondation dans la région semi-montagneuse à l'ouest de la Cote d'Ivoire: Apports des MNA et de l'imagerie satellitaire. Télédétéction 2005, 5, 53-67.

49. Koumassi, D.H.; Tchibozo, E.; Vissin, E.W.; Houssou, C.S. SIG et télédétection pour l'optimisation de la cartographie des risques d'inondation dans le bassin de la Sota au Bénin. Revue Ivoirienne Science Technologie 2014, 23, 137-152.

50. Nkeki, F.N.; Henah, P.H.J.; Ojeh, V.N. Geospatial techniques for the assessment and analysis of flood risk along the Niger-Benue basin in Nigeria. J. Geogr. Inf. Syst. 2013, 5, 123-135. [CrossRef]

51. OduroAmoako, P.Y.; Asanoah, K.A.; Mantey, P.P.; Ametefe, V.W.; Addabor, V.O.; Agbleze, K. Flood and Drought Risk Mapping in Ghana; 5-AAP Pilot Districts; African Adaptation Programme: Accra, Ghana, 2012.

52. Komi, K.; Amisigo, B.A.; Diekkrügger, B. Integrated flood risk assessment of rural communities in the Oti river basin, West Africa. Hydrology 2016, 3, 42. [CrossRef]

53. Tiepolo, M.; Braccio, S. Flood risk assessment at municipal level in the Tillabéri Region, Niger. In Planning to Cope with Tropical and Subtropical Climate Change; Tiepolo, M., Ponte, E., Cristofori, E., Eds.; De Gruyter Open: Warsaw, Poland; Berlin, Germany, 2016; pp. 221-242. ISBN 978-3-11-048079-5. Available online: https:/ / www.degruyter.com/view/product/473515 (accessed on 18 March 2018).

54. Kreft, S.; Eckstein, D.; Melchior, I. Global Climate Risk Index 2017; Germanwatch: Bonn, Germany, 2016.

55. Kappes, M.S.; Keiler, M.; von Elverfeldt, K.; Glade, T. Challenges of analyzing multi-hazard risk: A review. Nat. Hazards 2012, 64, 1925-1958. [CrossRef] 
56. IEC/ISO-Organisation Internationale de Normalisation. Norme Internationale. Gestion des Risques-Techniques d'évaluation des Risques; ISO: Geneva, Switzerland, 2009; ISBN 2-8318-1068-2.

57. Ozer, P.; Laminou, O.M.; Tidjani, A.D.; Djaby, B.; De Longueville, F. Evolution récente des extrêmes pluviométriques au Niger (1950-2014). Geogr. Ecol. Trop. 2017, 41, 375-383.

58. Mach, K.J.; Planton, S.; von Stechow, C. (Eds.) Annex II. Glossary. In Climate Change 2014: Synthesis Report. Contribution of WGI, II and III to the Fifth Assessment Report of the IPCC; IPCC: Geneva, Switzerland, 2014; pp. 117-130. Available online: https://www.ipcc.ch/pdf/assessment-report/ar5/syr/AR5_SYR_FINAL_ Glossary.pdf (accessed on 18 March 2018).

59. Crichton, D. The risk triangle. In Natural Disaster Management; Ingleton, J., Ed.; Tudor Rose: London, UK, 1999; pp. 102-103. ISBN 0953614018.

60. Cardona, O.D.; van Aalst, M.K.; Birkmann, J.; Fordham, G.; McGregor, G.; Perez, R.; Pulwarty, R.S.; Schipper, E.L.F.; Sinh, B.I. Determinants of risk: Exposure and vulnerability. In Managing the Risk of Extreme Events and Disastersto Advance Climate Change Adaptation; A Special Report of Working Group I and II of the IPCC; Field, G.B., V. Barros, T.F., Stocker, D., Qin, D.J., David, J.D., Gian-Kasper, P., Kristie, L.E., Michael, D.M., Katharine, J.M., Simon, K.A., et al., Eds.; Cambridge University Press: Cambridge, UK, 2012; pp. 65-108. Available online: http:/ / www.ipcc.ch/report/srex/ (accessed on 18 March 2018).

61. Funk, C.C.; Peterson, P.J.; Landsfeld, M.F.; Pedreros, D.H.; Verdin, J.P.; Rowland, J.D.; Romero, B.E.; Husak, G.J.; Michaelsen, J.C.; Verdin, A.P. A Quasi-Global Precipitation Time Series for Drought Monitoring; U.S. Geological Survey Data Series 832; U.S. Geological Survey: Tallahassee, FL, USA, 2014.

62. World Meteorological Organization and Global Water Partnership. Flood Mapping; WMO: Geneva, Switzerland, 2013.

63. R. of Niger. Repertoire Nationale des Localités-ReNaLoc; Institut National de la Statistique: Tunis, Tunisia, 2013.

64. Gumbel, E.J. Statistical Theory of Extreme-Values and Some Practical Applications; National Bureau of Standards: Applied Mathematics Series; National Bureau of Standards: Washington, DC, USA, 1954.

65. Svoboda, M.; Hayes, M.; Wood, D. Standardization Precipitation Index User Guide; World Meteorological Organization: Geneva, Switzerland, 2012.

66. R. of Niger; Region de Dosso; Commune rurale de Tounouga. Plan de Developpement Communal de la Commune Rurale de Tounouga 2014-2018, 2014; unpublished.

67. R. of Niger; Dosso Region; Commune rurale de Tanda. Plan de Développement Communal de la Commune Rurale de Tanda 2015-2019. PDC Acclimaté, 2015; unpublished.

68. R. of Niger; Région de Dosso; Commune rurale de Douméga. Plan de Développement de la Commune de Doumega Pour la Periode 2013-2017, 2013; unpublished.

69. R. of Niger; Région de Dosso; Commune urbaine de Doutchi. Plan de Développement Communal PDC Replanifié, 2017; unpublished.

70. R. of Niger; Région de Dosso; Commune rurale de Falmey. Plan de Développement Communal, 2015; unpublished.

71. R. of Niger; Région de Dosso; Commune rurale de Guéchémé. Plan de Développement Communal 2014-2018, 2014; unpublished.

72. Eau-Vive. Programme “Doutchi Climat” au Niger. Montreuil. Available online: https://ideas.asso.fr/ media/organism/eau-vive/projet/170509-Fiche-Projet-Doutchi-Climat.pdf (accessed on 24 February 2018).

73. UNCDF. Local Niger Moves to Phase 2. United Nations Capital Development Fund, 2017. Available online: https:/ / www.local-uncdf.org/news/local-niger-enters-phase-2 (accessed on 24 February 2018).

74. Ministère du Plan, de l'Aménagement du Territoire et du Développement Communautaire. PSRC Programme Strategique de Résilience Climatique. Zones D'intervention et Bénéficiaires des Activités du Projet. Available online: http:/ / psrcniger-ppcr.ne/index.php/pacrc/zone-d-intervention-et-beneficiaires (accessed on 24 February 2018).

75. Lux Dev. Programme d'Appui au Développement Agricole durable dans la Region de Dosso. Evaluation Finale. 2016. Available online: https://niger.luxdev.lu/en/documents/section/eval (accessed on 24 February 2018).

76. R. of Niger, Cabinet du Premier Ministre, CNEDD, FEM, PNUD. Rapport D'évaluation Finale du Projet PANA Resilience. 2014. Available online: www.preventionweb.net/files/RAPPORT\%20EVALUATION\% 20FINALE\%2014.doc (accessed on 24 February 2018). 
77. Alliance Mondiale Contre le Changement Climatique, Commission Européenne. La Résilience Climatique Pour un Développement Agricole Durable au Niger. Available online: http:/ / www.gcca.eu/fr/la-resilienceclimatique-pour-un-developpement-agricole/ (accessed on 24 February 2018).

78. R. of Niger, Unité de Coordination des Programmes du Millennium Challenge. PASEC-Projet D'appui à L'agriculture Sensible aux Risques Climatiques. Available online: http:/ / ucpmc.ne/programme-compact/ volet-co-financement/ projet-dappui-a-lagriculture-sensible-aux-risques-climatiques-pasec/ (accessed on 24 February 2018).

79. World Bank. Niger Safety Net Project. Implementation Status \& Results Report 3 May 2017. Available online: http:/ / projects.worldbank.org/P123399/niger-safety-net-project?lang=en\&tab=documents\&subTab= projectDocuments (accessed on 24 February 2018).

80. World Bank. PGRC-DU Projet de Gestion des Risques de Catastrophes et de Développement Urbain. Available online: https:/ / pgrcdu-niger.org/ (accessed on 24 February 2018).

81. Croix-Rouge de Belgique, Nigerienne Irish Red Cross. Evaluation Externe du Projet Renforcement de la Resilience Communautaire Dans la Commune Rurale de Kieché (Dogondoutchi, Niger). Rapport Final. Available online: https://www.croix-rouge.be/content/uploads/sites/11/2017/12/Niger_-R\% C3\%A9silience-communautaire-2014-2016.pdf (accessed on 24 February 2018).

82. Ibimet-CNR. Climate Change Adaptation, Disaster Prevention and Agricultural Development for Flood Security. Available online: https:/ / training.climateservices.it/anadia-niger/ (accessed on 5 March 2018).

83. World Bank. Project Appraisal Document on a Proposed Concessional Loan and Proposed Grant from the Pilot Program for Climate Resilience of the Strategic Climate Fund to the Republic of Niger for a Community Action Project for Climate Resilience. 19 December 2011. Available online: http:/ / projects.worldbank.org/ P125669/niger-community-action-project-climate-resilience?lang=en (accessed on 5 March 2018).

84. Biagini, B.; Bierbaum, R.; Stults, M.; Dobardzic, S.; McNeely, S.M. A typology of adaptation actions: A global look at climate action financed through the Global Environmental Facility. Glob. Environ. Chang. 2014, 25, 97-108. [CrossRef]

85. Desinventar. Available online: https:/ / www.desinventar.net/DesInventar/main.jsp (accessed on 3 March 2018).

86. Munich RE. NarCatService-Natural Catastrophe Know-How for Risk Management and Research. 2011. Available online: https://www.munichre.com/en/reinsurance/business/non-life/natcatservice/index. html (accessed on 12 March 2018).

87. R. of Niger. Enquête Conjointe sur la Vulnerabilité à L'insecurité Alimentaire des Menages au Niger (Décembre 2015-Janvier 2016); Institut National de Statistique-Niger and Système d'Alerte Precoce et Prevention des Catastrophes: Niamey, Niger, 2016.

88. R. of Niger, Ministère Interieur, DGPC. Situation inondations (à la date du 30 Septembre 2017).

89. R. of Niger, CC/SAP. Situation des dégats causes par les inondations. 2011-16.

90. R. of Niger, Direction régionale de l'agriculture. 2011-16. Liste des villages déficitaires à 50\% et plus de la Région de Dosso campagne hivernale 2011-17.

91. Descroix, L.; Guichard, F.; Grippa, M.; Lambert, L.A.; Panthou, G.; Mahé, G.; Gal, L.; Dardel, C.; Quantin, G.; Kergoat, L.; et al. Evolution of surface hydrology in the Sahelo-sudanian strip: An updated review. Water 2018, 10, 748. [CrossRef]

92. Adeloye, A.J.; Mwale, F.D.; Dulanya, Z. A metric-based assessment of flood risk and vulnerability of rural communities in the lower Shire valley, Malawi. PIAHS 2015, 370, 139-145. [CrossRef]

93. Fiorillo, E.; Crisci, A.; Issa, H.; Maracchi, G.; Morabito, M.; Tarchiani, V. Recent changes of floods and related impacts in Niger based on the ANADIA Niger flood database. Climate 2018, 6, 59. [CrossRef]

94. Ingram, K.T.; Roncoli, M.C.; Krishen, P.H. Opportunities and constraints for farmers of West Africa to use seasonal precipitation forecasts with Burkina Faso as a case study. Agric. Syst. 2002, 74, 331-349. [CrossRef] 
95. Conway, D.; Schipper, L.F. Adaptation to climate change in Africa: Challenges and opportunities identified from Ethiopia. Glob. Environ. Change 2017, 21, 227-237. [CrossRef]

96. Gemenne, F.; Blocher, J.; De Longueville, F.; Vigil Diaz Telenti, S.; Zickgraf, C.; Gharbaoui, D.; Ozer, P. Changement climatique, catastrophes naturelles et mobilité humaine en Afrique de l'Ouest. Geo-Eco-Trop 2017, 41, 317-337. article distributed under the terms and conditions of the Creative Commons Attribution (CC BY) license (http://creativecommons.org/licenses/by/4.0/). 